\title{
COVID-19 Salgını ve Özel Okul Ücret Politikaları: Kanuni ve Etik Çıkarımlar
}

\author{
Züleyha ERTAN-KANTOS ${ }^{1}$, Aslı YURTTAŞ ${ }^{2}$ ve Murat TAŞDAN ${ }^{3}$ \\ Öz
}

Bu araştırmanın temel amacı, COVID-19 salgınının Türkiye'de görülmeye başlamasından sonra özel okullarda yüz yüze eğitime ara verilmesinin ardından 2019-2020 öğretim ylı bahar dönemi ve 2020-2021 öğretim yllı güz döneminde özel okulların hizmet ve ücret politikaları hakkında veli görüşlerini ortaya koymaktır. Araştırma paralel karma desende gerçekleştirilmiştir. Araştırmada iki aşamalı örneklem alınmışır. Araştırmanın nicel örneklemi basit seçkisiz yöntemle, nitel örneklemi maksimum çeşitlilik örnekleme tekniğiyle oluşturulmuştur. Araştırmada 143 veliye ulaşılmıştır. Araştırmada veri toplama aracı olarak araştırmacılar tarafindan nicel ve nitel soruların bir arada bulunduğu "Salgın Süresince Özel Okulların Gelir ve Finansmanına Yönelik Veli Görüşleri” formu oluşturulmuştur. Özel okul velilerinin görüşleri doğrultusunda elde edilen bulgular; COVID-19 salgını süresince hanehalkının özel okul eğitimi harcamaları, özel okullarda öğrenci kayıt sözleşmelerinin durumu, özel okullara öğrenci kayıtları, özel okullarda karşılanmayan hizmetler ve bu hizmetlere ilişkin özel okulların ücret iadesi politikaları, özel okullara devlet desteği ve özel okulların giderlerinde azalma temaları altında incelenmiştir. Araştırmanın sonuçlarına göre, 2020-2021 öğretim yılında özel okul velileri özel okul ücretlerini yüksek bulmaktadır. Özel okul velileri özellikle yemek/kitap/kırtasiye/genel gider ücretleri ile çevrimiçi eğitim ücretini fazla bulmakta ve özel okul ücretlerinin ailelerinin gelirindeki artıştan daha fazla arttığını düşünmektedir. Bu nedenle hukukçu ve eğitimcilerden oluşan özel okullarla hiçbir organik bağı olmayan bir komisyon her iki tarafın isteklerini dinleyip özel okul velileri ve özel okul sahiplerinin uzlaşması için arabuluculuk görevi üstlenmelidir

Anahtar Kelimeler: COVID-19 salgını, Türkiye, özel okul, ücret politikası, veli

\section{COVID-19 Pandemic and Private School Fee Policies: Legal and Ethical Implications}

\section{Abstract}

The main purpose of this research is to reveal the views of parents on the service and fee policies of private schools in the spring semester of the 2019-2020 academic year and the fall semester of the 2020-2021 academic year, after the COVID-19 pandemic started to occur in Turkey as well as face-to-face education was suspended in private schools. The research was carried out in parallel mixed design. Two different samplings were taken in the study. The quantitative sampling of the research was created with the simple random method whereas the qualitative sampling was created with the maximum diversity sampling technique. 143 parents participated in the research. As a data collection tool the researchers created and used the "Parents' Opinions on the Income and Financing of Private Schools During the Pandemic" form in which quantitative and qualitative questions were combined, Findings obtained in line with the opinions of parents were examined under the themes of private school education expenditures of households, status of student enrollment agreements in private schools, student enrollment to private schools, services not covered in private schools and the refund policies of private schools for these services, state support to private schools and reduction in expenses of private schools during the COVID-19 pandemic.. According to the findings, private school parents find private tuition fees high in the 2020-2021 academic year. Parents of private schools especially find food / book / stationery / overhead fees and online tuition fees higher and think that private school fees have increased more than the family income increase. For this reason, a commission consisting of lawyers and educators that has no organic ties with private schools should listen to the requests of both parties and act as a mediator for the reconciliation of private school parents and private school owners.

Key Words: COVID-19 pandemic, Turkey, private school, fee policies, parent

\section{Atıf İçin / Please Cite As:}

Ertan-Kantos, Z., Yurttaş, A. ve Tașdan, M. (2022). COVID-19 salgını ve özel okul ücret politikaları: kanuni ve etik çıkarımlar. Manas Sosyal Arastirmalar Dergisi, 11(1), 158-175.

Geliş Tarihi / Received Date: 21.06.2021

Kabul Tarihi / Accepted Date: 18.11.2021

\author{
${ }^{1}$ Dr. - Milli Eğitim Bakanlığı, Ankara, Turkey, zulisertan@gmail.com \\ (D) ORCID: 0000-0002-3372-4967 \\ 2 Araştırma Görevlisi - Kafkas Üniversitesi Eğitim Fakültesi, asliorcan@gmail.com \\ (iD) ORCID: 0000-0003-0188-9887 \\ 3 Prof. Dr. - Kafkas Üniversitesi Eğitim Fakültesi, murattasdan@gmail.com




\section{Giriş}

COVID-19 salgının etkisiyle dünyada yaşanan kriz dalgaları her alanda kendisini göstermiştir. Eğitim bu kriz dalgalarından en çok etkilenen sektörlerin başında gelmektedir. COVID-19 salgınıyla birlikte alışlagelen geleneksel yüz yüze eğitim yerini çevrimiçi eğitime bırakmıştır. Çevrimiçi eğitime geçişteki amaç, öğrencilerin öğrenme kayıplarının önüne geçmektir (World Bank Report, 2020). Eğitimin çevrimiçi olması, eğitimin kamu okullarında ve özel okullarda yeniden yapilandırılması anlamına gelmekle birlikte aynı zamanda farklı konularda yeni sorunları da beraberinde getirmektedir. Eğitimin devam etmesi bir yerde çevrimiçi alt yapıya, çevrimiçi alt yapıya ulaşmak için de dijital kaynaklara(bilgisayar, tablet, telefona) ihtiyaç duyulmaktadır. Salgınla birlikte eğitimin çevrimiçi alana taşınması özel okullarda eğitimi, beklentiler, hukuk, eğitim üçgenine taşımışıtır. Dünya'da salgında özel okullarda eğitim bu üç alanda tartsşılmaya başlanmıştır. Beklentiler; veli beklentileri, özel okul yönetiminin beklentileri olarak sınıflandırılırken, okul sözleşmeleri; hukukun, verilen eğitimin niteliği ve niceliği ise eğitim alanında tartışılmaktadır. Ülkeler; veliler ve özel okullar arasında olan bu durumu, özel okul sözleşmelerine, kendi hukuk kuralları çerçevesinde çözmeye çalışmışlardır.

Türkiye'de COVID-19 salgını nedeniyle eğitim-öğretime 16 Mart 2020 tarihinden itibaren iki hafta ara verilmiş, yine Milli Eğitim Bakanlık kararı ile öğretim dönemi bitene kadar bu ara uzatılmıştır. 20202021 güz dönemi içinde 31 Ağustos 2020'de başlayan üç haftalık telafi eğitimi yapılmasına ve 21 Eylül 2020 tarihinden itibaren de yüz yüze öğretimin başlaması kararı verilmiştir. Bu salgın sürecinde özellikle özel okul velileri daha önce yapılan sözleşmelerin yenilenmesi ve çevrimiçi eğitim indirimine gidilmesi beklentileri içerisine girmişlerdir. Veliler, ekonomik olarak kendilerinin de zor durumda olduğunu, maddi olanaklarının azaldığını belirtmişlerdir. Yapılan araştırmada sosyal izolasyon sırasında eğitimin çevrimiçi olarak devam etmesini sağlayabilecek teknolojiye erişebilen daha yüksek gelirli nüfuslar arasında bile büyük bir eşitsizlik olduğu saptanmıştır (Nicola, Alsafi, Sohrabi, Kerwan, Al-Jabir, Iosifidis ve Agha, 2020). COVID-19 salgın sürecinde eğitimin her kademesinde yer alan öğretmen, öğrenci, veli, okul kavramlarına farklı yetkinlikler yüklenmiştir. Okullar eve taşınmış, veliler çocuklarına bazı sorumluluklarını yerine getirmede yardımcı olmuşlardır. Bu süreçte veliler, özel okullara devrettikleri birçok eğitim ve öğretim sorumluluğunu kendileri üstlenerek çocuklarının eğitimine daha fazla zaman ayırmak zorunda kalmışlardır. Okulların vermesi gereken, sosyal ve kültürel ekinlikler yarım kalmıştır. Akademik öğrenmenin gerçekleşmesi çevrimiçi verilen eğitimde, yüz yüze verilen eğitime göre daha zor ve az olmuştur. Bu durum Bao, Ou, Zhang ve Hogan (2020)tarafindan yapılan araştırmada ortaya konulmuştur. COVID-19 nedeniyle okullarının kapanması sırasında yapılan boylamsal araştırmada anaokulu çocuklarının okuma becerilerini \%66 daha yavaş kazandıkları belirlenmiştir. Okul kapanmadan anaokulu çocuklarının ortalama okuma puan kazancının 1 Ocak 2020 ile 1 Eylül 2020 arasında, \% 31 oranında 13,8'den 9,5'e düştüğü bulunmuştur.

Özel okullar, yönetmelikte veli isteğine bırakıldığı belirtilmesine rağmen 6 ay öncesinden yemek ve abartılı kırtasiye ücretlerini velilerden peşin almışlardır. Okul öğretmenlerinin ücretlerini kısa çalışma ödeneğinden ödemişlerdir. Özel okul velileri, yüz yüze eğitimin uzaktan eğitime denk olmadığını, sözleşmelerinde böyle bir madde olmadığını belirtmektedirler. Uzaktan çevrimiçi eğitimin yüz yüze eğitimle denk olamayacağı, eğitimle ilgili platformlarda vurgulanmaktadır. Çevrimiçi eğitimin, yüz yüze verilen eğitimdeki kazanımları karşılamayacağı UNICEF (2020), TEDMEM (2020), Bahçeşehir Üniversitesi (2020), Zhou (2020) tarafindan yapılan araştırmalarda ortaya konulmuştur. Özel okulların yönetimleri ücretlerinden hiçbir indirim yapılmayacağını, yani sözleşmelerde değişiklik yapılmayacağını açıklamışlardır. Veliler ise, kendilerine haksızlık yapıldığını ödedikleri ücretin karşılığını alamadıklarını belirtmişlerdir. Tüm bu yaşanılan olaylar, öğrenci velilerini ve özel okulların iletişiminin değişmesine yol açmış, farklı beklentiler oluşmuştur. Özel okullarda öğrenci kaybı yaşanırken, özel okullardan kamu okullarına doğru öğrenci nakli başlamıştır. Milli Eğitim Bakanlı̆̆1 2020 istatistiklerine göre okulöncesi eğitimde 289.213, ilkokulda 274.018, ortaokulda 347.495, ortaöğretimde 557.472 olmak üzere örgüt eğitimde ülke genelinde toplam 1.468 .198 öğrenci özel okullarda eğitim görürken (MEB, 2020, 41) 20202021 eğitim ögretim yllında yaklaşık 310 bin 530 öğrenci azalarak 1 milyon 157 bin 668 olmuştur (Kaplan, 2020 ). Özel okullardan kamu okullarına gelen her öğrenci; kamu okullarına daha fazla yatırım, daha fazla derslik yapılmasını gerektirecektir. MEB 2023 vizyon belgesinde özel öğretim kurumları "Eğitim sisteminde ciddi bir yük üstlenen özel öğretim alanı" olarak beyan edilmiştir (MEB, 2020, 21). Özel öğretim kurumları ve velileri MEB’in üzerindeki yükün azalmasına yardımcı olmaktadır. Bunun için Milli Eğitim Bakanlığı gerekli tespitleri yaparak, velilerin de taleplerini inceleyerek, yeni önlemler açılamalı, bu önlemlerden her iki tarafinda makul ölçülerde yararlanmasını sağlayacak tedbirler geliştirmelidir. 
Alanyazın incelendiğinde COVID-19 salgınının eğitime etkisiyle ilgili birçok araştırma olduğu görülmekle birlikte, COVID-19 salgını sürecinde özel okullar ve velileri arasında yaşanan sorunlarla ilgili araştırmaya rastlanmamıştır. Alanyazındaki bu boşluğa dikkat çekmek ve eğitim bilimleri alanına katkı sunması bakımından bu araştırma önemli görülmektedir. Araştırmada problemin karşlıklı iki tarafı olan özel okul velileri ve özel okul sahiplerinin görüşlerine başvurulması sorunun çok yönlü olarak ortaya konulmasına, okullar ve veliler arasında daha güvene dayalı bir iletişimin oluşmasına yol açacağ1 düşünülmektedir.

$\mathrm{Bu}$ araştırmanın temel amacı COVID-19 salgını nedeniyle özel okullarda yüzyüze eğitime ara verilmesinin ardından bu süreçteki hizmet ve ücret politikalarına ilişkin özel okul velilerin görüşlerini ortaya koymaktır. Bu doğrultuda şu sorulara yanıt aranmaktadır:

1. 2019-2020 öğretim yllı bahar döneminde salgın sürecinde özel okulların hizmet ve ücret politikalarına (öğrencilerin sunulan hizmetlerden faydalanma durumu, velilerin memnuniyet düzeyi, özel okulların ücret iadesi politikası) ilisskin özel okul velilerinin görüşleri nasıldır?

2. 2020-2021 öğretim y1lı güz döneminde salgın süresince özel okulların hizmet ve ücret politikaları (velilerin özel okul tercihi nedenleri, öğrenci kayıt sözleşmeleri, uzaktan eğitim yoluyla verilen ders sayısı ve süresi) ilişkin özel okul velilerinin görüşleri nasıldır?

3. Covid-19 salgın süresince özel okullardaki hizmet ve ücret politikasına ilişkin tartışmalı (ikilemli) uygulamalara ilişkin özel okul velilerinin görüşleri nasıldır?

\section{Yöntem}

Araştırma sorularına yanıt bulmak üzere yalnızca nitel ya da nicel bilgilerin yeterli olmayacağı düşünülmüş, araştırmada karma yöntem ve zenginleştirilmiş (üçgenleme) paralel karma desenden faydalanılmıştır. Zenginleştirilmiş paralel karma desende amaç hem nicel, hem de nitel yöntemin avantajlardan faydalanarak bulguları doğrulamak ve güvenirliği arttırmaktır (Lodico Spaulding ve Voegtle, 2006). Bu bağlamda, özel okul velilerinin görüşlerine göre COVID-19 salgını süresince özel okulların gelir ve finansmanı olgusunun anlamı ve doğasına ilişkin durumu betimlemek üzere nicel yaklaşımdan, bu olguyu derinlemesine araştırmak üzere nitel yaklaşımdan faydalanılmıştır.

\section{Çalışma Grubu}

Araştırmanın nicel çalışma grubunu COVID-19 salgını süresince özel okulların gelir ve finansmanına ilişkin veli görüşlerini almak üzere, 7 coğrafi bölgeden 143 katılımcı oluşturmaktadır. Katılımcıların belirlenmesinde kolayda örnekleme tekniğinden faydalanılmıştır. Katılımcılara ilisskin demografik bilgiler Tablo 1' de verilmektedir.

Tablo 1. Katulmallara İliskin Demografik. Bilgiler ( $n=143)$

\begin{tabular}{|c|c|c|c|}
\hline & Değisken & $n$ & $\%$ \\
\hline \multirow{6}{*}{ Yaşanılan Bölge } & Akdeniz & 7 & 4,9 \\
\hline & Doğu Anadolu & 2 & 1,4 \\
\hline & Ege & 14 & 9,8 \\
\hline & Güneydoğu Anadolu & 2 & 1,4 \\
\hline & İç Anadolu & 37 & 25,9 \\
\hline & Marmara & 81 & 56,6 \\
\hline \multirow{4}{*}{ Yerleşim birimi } & Köy/Kasaba & 2 & 1,4 \\
\hline & İlçe Merkezi & 11 & 7,7 \\
\hline & Şehir Merkezi & 15 & 10,5 \\
\hline & Büyükşehir & 115 & 80,4 \\
\hline \multirow{3}{*}{$\begin{array}{l}\text { Çocuğun yer aldığı eğitim } \\
\text { kademesi }\end{array}$} & İlkokul & 65 & 45,5 \\
\hline & Ortaokul & 63 & 44,0 \\
\hline & Lise & 15 & 10,5 \\
\hline
\end{tabular}

Tablo 1'e göre göre, katıllmcılara ilişkin demografik bilgiler, yaşanılan bölge -Akdeniz ( $\mathrm{f}=7$ ), Doğu Anadolu ( $\mathrm{f}=2$ ), Ege ( $\mathrm{f}=14$ ), Güneydoğu Anadolu ( $\mathrm{f}=2$ ), İç Anadolu ( $\mathrm{f}=37$ ), Marmara ( $\mathrm{f}=81)-$, yerleşim birimi -köy/kasaba ( $\mathrm{f}=2)$, ilçe merkezi ( $\mathrm{f}=11)$, şehir merkezi ( $\mathrm{f}=15)$, büyükşehir ( $\mathrm{f}=115)$-, velisi olduğu öğrencinin yer aldığ1 eğitim kademesi -ilkokul ( $\mathrm{f}=65)$, ortaokul ( $\mathrm{f}=63)$, lise ( $\mathrm{f}=15)$ değişkenleri açısından değişkenlik göstermektedir. 
Araştırmanın nitel çalışma grubunu COVID-19 salgını süresince özel okulların gelir ve finansmanı olgusuna ilişkin velilerin görüşlerini derinlemesine incelemek ve çeşitli görüşleri ortaya çıkarmak üzere kolayda örnekleme tekniğinden faydalanılmıştır. Araştırmada nicel ve nitel veriler eş zamanlı olarak toplanmışır. Araştırmanın nitel verileri farklı bölgelerde yaşayan, farklı deneyimlere ve farklı demografik özelliklere sahip 143 katılımcıdan yarı yapılandırılmış görüşme formu aracılığıyla toplanmıştır.

\section{Veri Toplama Araçları}

Araştırmada nitel ve nicel veriler, yazarlar tarafindan geliştirilen "Salgen Süresince Özel Okullarn Gelir ve Finansmannna Yönelik Veli Görïslern" anket formu ve "Salgn Süresince Özel Okullarn Gelir ve Finansmanna Yönelik Veli Görüsleri”" görüşme formu kullanılarak elde edilmiştir. Anket formu; katılımcıların araştırmaya katılmak için uygun özelliklerde olduklarını ve araştırmaya gönüllü olarak katıldıklarını belirttikleri iki sorudan oluşan onay formu, katıllımcıların demografik özellikleri ile kişisel bilgilerini belirttikleri üç sorudan oluşan kişisel bilgiler formu ve 11 kapalı ve çoklu seçenekten oluşan nicel, altı açık uçlu nitel araştırma soruları bölümünden oluşmaktadır. Anket formunda yer alan sorular şu şekilde örneklendirilebilir:

Kapalı uçlu soru örneği: Salgın süresince özel okul tarafından karşılanmayan hizmetlere (yemek, servis, gezi vb.) ilişkin okulunuzdan ücret iadesi alabildiniz mi?

a) Evet, tamaminı aldik.

b) Evet, iade yapılması gereken ücretin bir kısmını aldık.

c) Hayır, ücret iadesi alamadık.

Açık uçlu soru örneği: Salgın süresince özel okul tarafindan karşılanmayan hizmetlere (yemek, servis, gezi vb.) ilişkin okulunuzun ücret iadesi politikasına ilişkin görüşlerinizi ve deneyimlerinizi (varsa) lütfen yazinız.

Nicel sorular, kapalı uçlu ve çoklu seçenekli sorulardan oluşturulmuştur. Nicel sorular, salgın süresince özel okul velilerinin; a) özel okul eğitimi için ayırdı̆̆ bütçe, b) aile gelirinde yaşanan değişim, c) velilerin özel okul ücretlerini nasıl bulduğu (yüksek-normal-düşük), d) velilerin öğrenci kayıt sözleşmelerini okuyup anlayarak imzalama durumları, e) gelecek eğitim öğretim döneminde özel okula kayıt yaptırmaya yönelik düşünceleri, f) özel okullardan aldığ1 hizmetler, g) özel okulların planladıkları ders sayısı ve süresinin özel okul ücretleri ile ilişsine yönelik düşünceleri h) ücret iadesi alma durumları, i) ücret iadesi alma hususunda izledikleri yol, j) ücret iadesi beklentileri, k) özel okul tercih nedenleri gibi göstergeleri içeren bilgilere yönelik hazırlanmıştır.

Araşı̧ımanın nitel verileri, katılımcıların salgın süresince özel okulların gelir ve finansmanına ilişkin deneyim ve algılarını ortaya çıkarmak üzere toplanmışır. Araştırmanın deseni zenginleştirilmiş karma desen olarak belirlenmiştir. Bu doğrultuda nicel sorular, nicel bulguları doğrulamak ve elde edilen bulguları zenginleştirmek üzere nicel formda yer alan sorulara paralel olarak hazırlanmıştır.

Anket formunun ulaşılmak istenilen yapıyı temsil edip etmediği (geçerlik) iki eğitim yönetimi alan uzmanı ve iki özel okul müdürü tarafından görüş alınarak düzenlenmiştir. Salgın döneminde anket sorularının "Google Forms"a aktarılarak verilerin çevrimiçi olarak toplanmasının uygun olduğu düşünülmüştür. Ankette yer alan kapalı uçlu sorulara verilecek olası seçenekleri arttırmak ve olası hataları görmek üzere 20 özel okul velisine gönderilerek pilot çalışma yapılmıstır. Pilot çalışma sonucunda anket formunun incelenen yapıyı tutarlı ve doğru olarak temsil edip etmediği (güvenirlik) test edilmiş, anket formu son şeklini almıştır. Veriler, 10-23 Eylül 2020 tarihleri arasında Google Forms üzerinden çevrimiçi olarak toplanmıştır. Hatalı örnekleme ulaşmamak ve çevrimiçi veri toplama sürecinde yaşanılabilecek aksaklıkları en aza indirmek üzere, anket yalnızca özel okul velilerinin bulunduğu sosyal mesajlaşma ağlarına atılmıştır. Yeterli sayıda katıllımcıya ulaşıldığı düşünüldüğünde anket sonlandırılmıştır.

\section{Verilerin Analizi}

"Salgn Süresince Özel Okullarn Gelir ve Finansmanna Yönelik Veli Görïșleri” anket formunda yer alan kapalı uçlu sorulardan elde edilen nicel veriler, betimleyici istatistikler kullanılarak frekans ve yüzde olarak hesaplanmıştır. Nitel görüşme formundan elde edilen veriler ise, betimletici ve açıklayıcı biçimde analiz edilmiştir. Katılımcıların ifadeleri doğrudan alıntılarla iç güvenirlik sağlanmışır. Araştırmada önce benzerlik ve farklı olan ifadeler bir araya getirilerek temalar ve alt temalar oluşmuştur. Araştırmanın güvenirliğinin sağlanması için tema ve alt temaların belirlenmesinde eğitim bilimleri alanında çalışan iki araştırmacının da 
görüşlerine başvurulmuştur. Verilerin analizinde görüşlerine başvurulan velilere( $K: 1, K: 2, K: 3 \ldots$.$) şeklinde$ kod numarası verilmiştir. Katılımcılanın anket formuna verdiği yanıtlar araştırmacılar tarafindan kodlandıktan sonra bir kod anahtarı oluşturulmuş ve alanda uzman dört akademisyen her görüşme formu için görüşme kod anahtarını doldurmuş böylece kodlayıcılar arasındaki tutarlılık hesaplanmıştır. Kodlayıcilar tarafindan "görüş birliği" ve "görüş ayrillğı" olan kodlar belirlenmiştir. Toplanan verilerden yola çıkarak araştırmaya özgü kod, kategori ve temalara ulaşılmışır.

\section{Bulgular}

"Salgm Süresince Özel Okullarn Gelir ve Finansmanna Yönelik Veli Görüsleri” anket formundan elde edilen nitel ve nicel veriler analiz edilerek birleştirilmiş, bulgular COVID-19 salgını süresince hanehalkının özel okul eğitimi harcamaları, özel okullarda öğrenci kayıt sözleşmelerinin durumu, özel okullara öğrenci kayıtları, özel okullarda karşılanmayan hizmetler ve bu hizmetlere ilişkin özel okulların ücret iadesi politikaları, özel okullara devlet desteği ve özel okulların giderlerinde azalma temaları altında incelenmiştir.

\section{COVID-19 Salgını Süresince Hanehalkının Özel Okul Eğitimi Harcamaları}

Özel okul eğitimine yapılan harcamalar, hanehalkı gelirinin büyük bir kısmını oluşturmaktadır. Tablo 2' de açıklandığı üzere, ankete katılan velilerin \%37'si öğrencinin özel okul eğitimi için 35.001 TL ve üzeri, \%31'i 25.001-35-000TL arasinda, \%26's1 15.001-25.000TL arasinda ve \%6's1 15.000 TL ve alt harcama yaptığını ifade etmektedir. Ankete katılan velilerin \%85' i özel okul ücretlerini yüksek bulduğunu belirtmesi ise, birçok velinin çocuklarının eğitimi için yapılan harcamaların isteğe bağlı bir ekstra değil, zorunlu bir masraf olduğunu düşündüğünün göstergesi olarak karşımıza çıkmaktadır.

Tablo 2. COVID-19 Salgm Süresince Hanehalkı Geliri (n=143)

\begin{tabular}{|c|c|c|c|}
\hline & Değisken & $n$ & $\%$ \\
\hline \multirow{4}{*}{$\begin{array}{l}\text { Özel okul eğitimine ayrllan } \\
\text { bütçe }\end{array}$} & 35.001 TL ve üzeri & 15 & 10,5 \\
\hline & $25.001-35.000 \mathrm{TL}$ & 53 & 37,1 \\
\hline & $15.001-25.000 \mathrm{TL}$ & 37 & 25,9 \\
\hline & 15.000 TL ve altı & 9 & 6,3 \\
\hline \multirow{3}{*}{ Hanehalkı gelirinde değişim } & Gelir azald 1 & 82 & 57,3 \\
\hline & Gelir arttı & 14 & 9,7 \\
\hline & Gelir değişmedi & 50 & 35 \\
\hline \multirow{3}{*}{ Özel okul ücretleri } & Yüksek & 121 & 84,6 \\
\hline & Normal & 16 & 11,2 \\
\hline & Düşük & 6 & 4,2 \\
\hline
\end{tabular}

COVID-19 salgınının eğitim harcamalarına etkisini değerlendirmek üzere, eğitim hizmeti ödemelerinin bankalar aracillğıyla gerçekleştirilmesi zorunlu hale getirilmesi bilgisini kullanarak 2020 yıli’na ait Bankalararası Kart Merkezi (BKM) verilerini ve TÜIK tarafından yayımlanan 2019 y1l hanehalkı eğitim harcamaları verileri kullanılmıştır. TUİK tarafindan yayımlanan verilere göre Türkiye'de 2019 yllında yapılan eğitim harcamalarının \%20,8’i hanehalkları tarafindan gerçekleştirilmiştir (TÜİK, 2020). Hanehalklarının eğitim harcamalarına katkısının, düşük gelirli ülkelerde (\%29), yüksek gelirli ülkelerden fazla olduğu bilinmektedir (UNESCO, 2019 Akt: Korlu, 2020). Bu durum, düşük ve orta gelirli ülkelerde hem eğitim harcamalarının daha az gerçekleştiği, hem de hanehalkılarına yüklendiği anlamına gelmektedir. Bankalararası Kart Merkezi (BKM) verilerine göre, 2020'nin ilk üççeyreğinde eğitim sektörü harcamalarında işlem tutarı 19.261 Milyon TL olmuştur. Bu rakam 2019 yllında yapılan 26.191 Milyon TL lik eğitim harcamalarından neredeyse $\% 25$ daha azdır (BKM, 2020). Türkiye' de hanehalkları tarafindan yapılan eğitim harcamalarının diğer ülkelere kıyasla oldukça yüksek olmasına rağmen, 2020 yılında eğitim sektörü harcamalarında büyük bir düşüş yaşanması şüphesiz ki salgin döneminde yaşanan ekonomik durgunluk ve hanehalklarının gelir düzeyinde yaşanan düşüş ile ilişkilidir. Nitekim ankete katılan velilerin $\% 57,3$ 'ü hanehalkı gelirinde düşüş yaşandığını belirtmiştir.

\section{COVID-19 Salgını Süresince Özel Okul Öğrenci Kayıt Sözleşmelerinin Durumu}

Dünya Sağllk Örgütü tarafindan COVID-19'un salgın olarak tanımlanmasıyla birlikte, özel okul sözleşmelerinde yer alan mücbir sebep maddesinin meşru hale geldiği görülmektedir. Bu maddelerin çoğu, hiç kimsenin gerçekten beklemediği savaş ve terör gibi tek seferlik olayların üstesinden gelmek için eklenmiştir. Nitekim, ankete katılan velilerin \%69'unun öğrenci kayıt sözleşmesinde yer alan maddeleri okuyup anlayarak imzalamadığı görülmektedir. Okulların fiziksel olarak kapatılmasının ardından öğrenci 
kayıt sözleşmelerinde yer alan maddelere ilişkin farkındalık yükselmiş ve bu maddeler daha önemli hale gelmiştir. Ankete katılan veliler, öğrenci kayıt sözleşmelerinde yemek/kitap ücretinin kayıt için zorunlu tutulması, ücret iadeleri ile ilgili maddelerin okul lehine düzenlenmesi, uzaktan eğitim ücreti ve koşulları ile ilgili maddelerin bulunmaması konularında rahatsılıklarını dile getirmişlerdir. Özel öğretim kurumları öğrenci kayıt sözleşmelerinde yer alan ve velilerin rahatsızlık duydukları konular Tablo 3'de açıklanmaktadır:

Tablo 3. COVID-19 Salgzn Süresince Özеl Okul Ögrrenci Kaynt Sǫ̈lessmelerinin Durumu

\begin{tabular}{|c|c|c|c|}
\hline Değişken & & $n$ & $\%$ \\
\hline \multirow{2}{*}{ Öğrenci kayıt sözleşmelerini okuyup anlayarak imzalama durumu } & Evet & 44 & 30,8 \\
\hline & Hayır & 99 & 69,2 \\
\hline TOPLAM & & 143 & 100 \\
\hline Kod & & f & $\%$ \\
\hline ÖKS*'nde Yemek/kitap ücretlerinin zorunlu tutulması & & 67 & 42,7 \\
\hline ÖKS’nde Ücret iadeleri ile ilgili maddelerin okul lehine düzenlenmesi & & 46 & 29,3 \\
\hline ÖKS'nde uzaktan eğitim ücreti ve koşullarını düzenleyen maddelerin yokluğu & & 44 & 28,0 \\
\hline & TOPLAM & 157 & 100 \\
\hline
\end{tabular}

*ÖKS: Öğrenci Kayıt Sözleşmesi

Yemek/kitap ücretlerinin zorunlu tutulması: Ankete katılan velilerin üçte birinden fazlası özellikle yemek ve kitap ücretlerinin öğrenci kayıt sözleşmelerini imzalamak için zorunlu tutulması konusunda rahatsızlık duyduklarını belirtmişlerdir. "Yillardır yemek ücretinin ödenmesini ve okulun kendi bazurlamıs olduğu kertasiye kolisinin alnmasin zorunlu tutuyorlar. Hem de bunlarn ürretini kaynt döneminde peşin olarak talep ediyorlar. Ancak ücret iadesinin gerektiği durumda kendileri kesinti yaparak ileri tariblerde ödeme yapacaklarm söylïyorlar." K:111. "Özellikle kitap ve yemek ücretlerinin çok sişirilmis olduğunu düssünüyorum. Ayrica bunlar almamak, başka yerden temin etmek, gibi bir şansinı yok. Mecbur borakellyorsunuz:" K:140. Okulların fiziksel olarak kapatılmasını gerektiren durumlarda hem ücret iadesi sürecinde yaşanan sıkıntıların (bkz. okulların fiziksel olarak kapatılması sırasında ücret iadeleri) bir sonucu olsa da salgin öncesinde de birçok veli bu dayatmadan rahatsızlık duymaktadır.

Ücret iadeleri ile ilgili maddelerin okul lehine düzenlenmesi: Ankete katılan velilerin üçte biri ücret iadeleri ile ilgili maddelerin okul lehine düzenlenmesi konusunda rahatsızlık duyduklarını belirtmişlerdir. "Kaynt sildirmeye karar verildig̈inde kaynt ücretinden \%10 kesinti yapılacak olması ve iadenin 2-3 ay gibi uzunca bir süre yapılmaması! Yemek ücretlerinin kayıt esnasinda 1 yullı. peşin alnması! Genel gider ücretlerinin ne için ödendiğine dair bir açılamanm olmayışı!...” K:59.

Uzaktan eğitim ücreti ve koşullarını düzenleyen maddelerin yokluğu: Ankete katılan velilerin üçte biri öğrenci kayıt sözleşmelerinin yeni kayıt döneminde uzaktan eğitim koşullarına göre yeniden düzenlenmesi gerektiğini belirtmişlerdir. "Ben kaydımı, salgin ortaya çıkmadan önce Şubat 2020 de erken kayıt ile yaptım. Salgin sonrası kaynt yaptursaydım, mutlaka sözlessmede uraktan eğitim kosullarmm yazıl olmasim ve

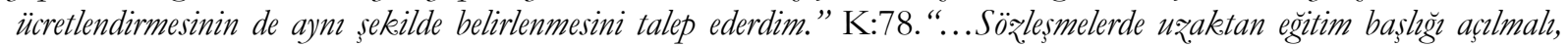
uzaktan eğitim kural ve ücretleri açıklanmalıdrr.” K:33. Özel okul mevzuatında ve öğrenci kayıt sözleşmelerinde yeri olmamasına rağmen, özel okul, veli ile uzaktan eğitim verilmesi hususunda anlaşabilmekte ve uzlaşabilmektedir. Ancak bu uzlaşma yeni bir sözleşmenin konusudur. Uzaktan eğitimin MEB tarafindan da veriliyor olması, özel okulların sunmuş olduğu eğitim hizmetini de meşrulaştırmaktadır (Bulut, 2020, 14 May1s).

\section{COVID-19 Salgını Süresince Özel Okullara Öğrenci Kayıtları}

Salgın döneminde velilerin özel okul ücretlerini ödemekte zorlanması, öğrencilerin özel okullardan devlet okullarına nakli, orta ve düşük ücretli okullar için daha az öğrenci kaydı anlamına gelmektedir. Özel okullardan devlet okullarına nakil olan öğrenci sayılarını içeren detaylı resmi bir veri olmamasına rağmen, bazı özel öğretim kurumlarının okul kapatmayla karşı karş̧ıa kalabileceği olasıllğını düşündürmektedir. Özel öğretim kurumlarının sayıca azalması ve bu öğrencilerin devlet okullarına geçişi, devlet okullarının kapasitesinin ve kamu eğitim harcamalarının başa çıkmakta zorlanacağı büyük bir öğrenci akınını oluşturabilir. Nitekim Tablo 4’te açıklandığı üzere ankete katılan velilerin, \%24’ü önümüzdeki y1l için erken 
kayıt yaptırmayı düşündüğünü, \%61’i kayıt yaptırmayı erteleyeceğini, \%15’i ise özel okullara yerine devlet okullarını tercih edeceğini ifade etmiştir. Özel okul velileri çocuklarının eğitimi için özel okulu tercih etme nedenlerini birden fazla seçenek işaretleyebildikleri anket sonuçlarında, eğitim-öğretim hizmetinin niteliği ( $\mathrm{f}=113)$, yabanc1 dil eğitimi ( $\mathrm{f}=93$ ), okul-veli iletişiminin güçlü olması $(\mathrm{f}=78)$, sosyal faaliyetlerin çeşitliliği $(\mathrm{f}=58)$, okulun fiziki olanakları $(\mathrm{f}=65)$, öğrencinin 1srarı $(\mathrm{f}=45)$, rehberlik hizmetlerinin niteliği $(\mathrm{f}=43)$, okulda bulunma saatlerinin uzun olması $(\mathrm{f}=41)$ olarak belirtmişlerdir. Bu doğrultuda, salgin döneminde, özel okulların tercih edilmesindeki birçok neden uzaktan eğitim süreciyle birlikte ortadan kalkmış gibi görünmektedir.

Tablo 4. COVID-19 Salgın Süresince Özel Okullara Ögrrenci Kayıtları

\begin{tabular}{|c|c|c|c|}
\hline Değişken & & $n$ & $\%$ \\
\hline \multirow{8}{*}{ Velilerin özel okul tercih nedenleri } & Eğitim öğretim hizmetlerinin niteliği & 113 & 79 \\
\hline & Yabancı dil eğitimi & 93 & 65 \\
\hline & Okul veli iletişiminin güçlü olması & 78 & 54,6 \\
\hline & Okulun fiziki olanakları & 65 & 45,5 \\
\hline & Sosyal faaliyetlerin çeşitliliği & 58 & 40,1 \\
\hline & Velisi olduğu öğrencinin ısrarı & 45 & 31,5 \\
\hline & Rehberlik hizmetlerinin niteliği & 43 & 30 \\
\hline & Öğrencinin okulda bulunma saatlerinin uzun olması & 41 & 28,7 \\
\hline Değişken & & $n$ & $\%$ \\
\hline \multirow{3}{*}{$\begin{array}{l}\text { Velilerin önümüzdeki eğitim öğretim } \\
\text { yllında özel okula kayıt yaptırma } \\
\text { durumu }\end{array}$} & Erken kayıt düşünüyor & 34 & 23,8 \\
\hline & Erken kayıt yaptırmayı düşünmüyor & 87 & 60,9 \\
\hline & Devlet okuluna kayıt yaptıracak & 22 & 15,3 \\
\hline TOPLAM & & 143 & 100 \\
\hline
\end{tabular}

Yukarıda açıklanan bu iki bulgu, özel okullardan devlet okullarına büyük bir öğrenci göçünün habercisi olarak görülebilir. Özel okul kayıtlarındaki düşüş ve özel okulların sayısında da azalma olarak algılanabilir. Böyle bir durum devlet okullarının kapasitesini ve kamu eğitim harcamalarını zorlayacaktır. Bu duruma salgın döneminde sosyal mesafe tedbirleri açısından baktığımızda, devlet okullarının sosyal mesafe tedbirlerini karşılamasının imkânsızlı̆̆1 da eklenecektir.

\section{COVID-19 Salgını Süresince Özel Okullarda Karşılanmayan Hizmetler ve Bu Hizmetlere İlişkin Özel Okulların Ücret İadesi Politikaları}

Öğrenci kayıt sözleşmelerinde yer alan mücbir sebep maddesi, sözleşmeden doğan yükümlülüklerin artık yerine getirilemediği, taraflar arasında yapılan pazarlığın temel niteliğinin değiştiği durumları ifade etmektedir. Mücbir sebep, taraflardan herhangi birine, kendi kontrolleri dişındaki bir olay nedeniyle sözleşmeden doğan yükümlülüklerini yerine getirmemelerini gerekçelendirme hakk1 verir (Eren, 2016). Sözleşmede yer alan bu madde ile işini kaybeden veliler, çocuklarının kaydını okuldan almak isteyebilir, dönem ücretlerini ödemekten vazgeçebilir veya okullar yüz yüze eğitime geçtiğinde çocuklarının eğitimine devam etmesini isteyebilirler. Özel okullar, okul sözleşmelerinde sunmay1 taahhüt ettikleri hizmetleri sağlayamayacaklarının farkında olmasına rağmen, gelirlerinden feragat etme konusunda istekli görünmemektedirler. Şekil 1' de görüldüğü üzere, ankete katılan veliler salgin öncesinde özel okulların sunmayı taahhüt ettiği hizmetlerden öğrencilerin ya hiç faydalanamadıklarını ya da kısmen faydalanabildiklerini ifade etmişlerdir. Veliler;

a) Eğitim hizmetleri: Öğrencilerin \%98'inin eğitim öğretim hizmetlerinden kısmen faydalandı̆̆ını (f=140), \%2'si ise (f=3) hiç faydalanamadığı̆ı;

b) Rehberlik hizmetleri: Öğrencilerin \%14'ünün rehberlik hizmetlerinden faydalandı̆̆ını (f=20), \%52'sinin kısmen faydalandığını, \%34'ünün ise (f=48) hiç faydalanamadığını,

c) Ölçme ve değerlendirme hizmetleri: Öğrencilerin \%16' sının ölçme ve değerlendirme hizmetlerinden faydalandığını ( $\mathrm{f}=23$ ), \%37'si kısmen faydalandığını ( $\mathrm{f}=53$ ), \%47'sinin ise ( $\mathrm{f}=67$ ) hiç faydalanamadığını, 
d) Yemekhane ve servis hizmetleri: Yemekhane ve servis hizmetlerinden öğrencilerin hiç faydalanmadığını ( $\mathrm{f}=143)$,

e) Diğer hizmetler: Revir, kulüpler, sanatsal ve sportif faaliyetler, kütüphane ve laboratuvar hizmetleri gibi hizmetlerden ise, öğrencilerin hiç faydalanmadığını ( $\mathrm{f}=143)$ belirtmiştir.

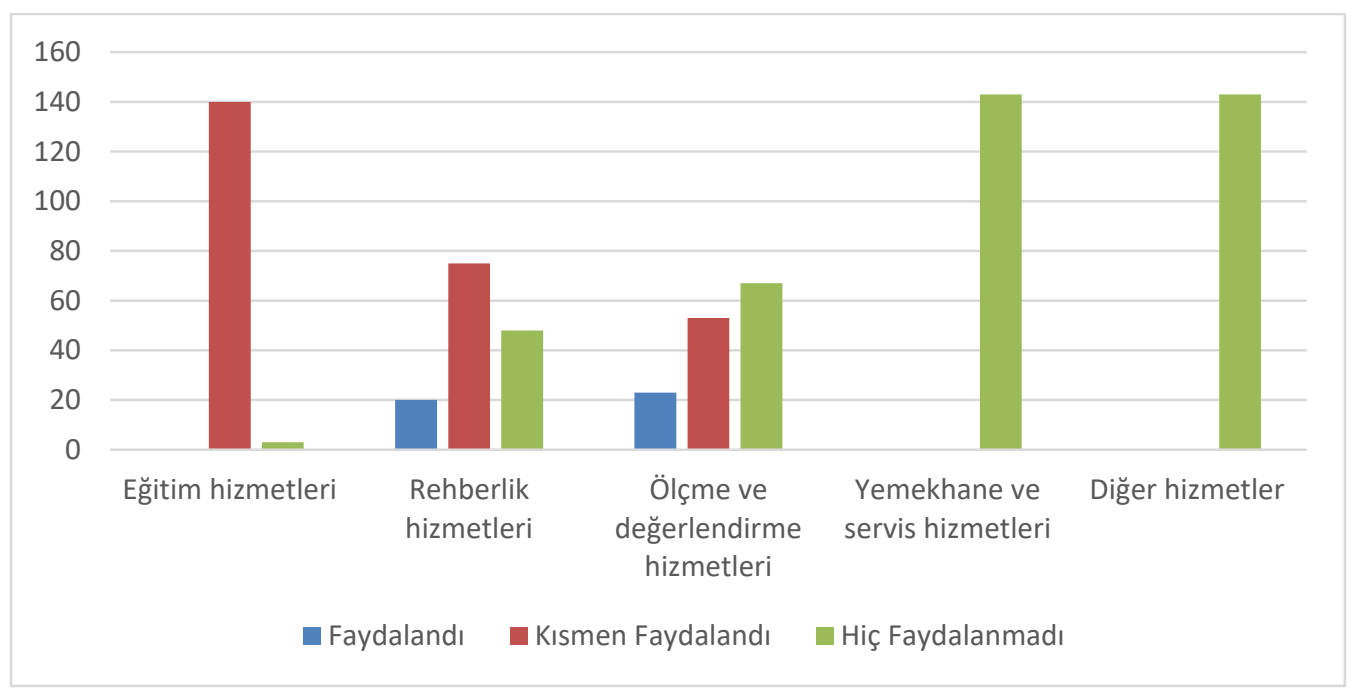

Şekil 1. COVID-19 Salgmı Süresince Özel Okullarn Sunduğu Hiæmetlerden Ögrrencilerin Faydalanma Durumu

Okulların çoğu, sözleşmede öngörülen tüm hizmetleri artık yerine getiremeyeceklerini velilere bildirmiş, uzaktan eğitime geçiş ile birlikte dersler, devlet okullarına kıyasla daha uzun ve yoğunlaştırılmış olarak sunulmuştur. Nitekim özel okulların telafi eğitim ile öğrenci kayıt sözleşmelerinde taahhüt ettikleri yükümlülükleri yerine getireceğini savunan ve getiremeyeceği iddia eden iki görüş oluşmuştur:

Özel okulların taahhüt ettikleri yükümlülükleri yerine getireceğini savunan görüşlerin kaynağı olarak, Milli Eğitim Bakanllğı, Türkiye Özel Okullar Derneği, Özel Öğretim Derneği ve Türkiye Özel Okullar Derneği Yüksek İstişare Kurulu'nun açıklamaları gösterilmektedir (Hukuki Haber, 2020, 23 Nisan). Ankete katılan velilerin \%56's1, özel okulların uzaktan eğitim süresince planlamış olduğu ders sayısı ve süresinin eğitim ücretinde olası bir ücret iadesini ortadan kaldırmak için daha uzun ve yoğunlaştırılmış olduğunu belirtmişlerdir. "Cocuğum 1.smnf ve günde 9 ders veriliyor. Kesinlikle hepsine girmiyor. Sadece ana derslere

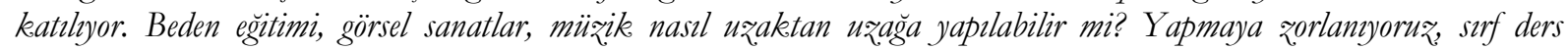
yaptık iade istemeyiniz diye." . "Bir çocuğun sabah 9:00 dan akșam 17:00 ye kadar ekranda olması çok sağhksı\%. CIMER'e kadar şikâyet ettim ama veliler para verdik daba şok ders olmall baskısı yaptıklar için okul geri adım atmadr." $\mathrm{K}: 87$

Mücbir sebepten dolayı özel okulların, ücret iadesi yapması gerektiğini savunan görüşlerin kaynăg1 olarak, avukatlar tarafindan ileri sürülen görüşler ve Tüketici Sorunları Derneği’nin açıklamaları gösterilmektedir (Hukuki Haber, 2020, 23 Nisan). Nitekim ankete katılan velilerin ücret iadesine ilişskin beklentisinin, uzaktan eğitim yoluyla sunulması mümkün olmayan hizmetler ve yine uzaktan eğitim yoluyla daha düşük standartlarda sunulan hizmetler için yemek ve servis ücretleri dişında ek indirim talebi olduğu anlaşılmaktadır. "Biz erken kaynt döneminde yüz yü̈re eğitim için kaynt yaptordık ki o zaman bile beklentimiz̨i tam

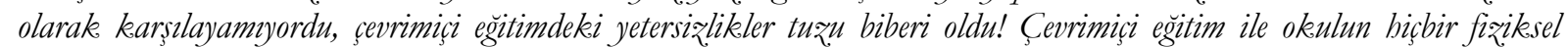
imkân kullanulmadı̆g gibi söz. verilen sosyal aktiviteler, geži programlar, müsamereler de yapılamadı. Genel gider adı altunda bu faaliyetlerin ödemesi de yapılmıstı! Dolayısyla özel okullar \%50 indirim yaparak bi₹ velilerin paralarm geri iade etmeliler!' K:87. Bazı veliler, okullar tarafindan sunulan ücret indirimlerinin, okulun sunmayı taahhüt ettiği hizmetler ve öğretim programı dışında kalan faaliyetlerdeki kesintilere kıyasla yeterli olmadığını veya diğer okulların sunduklarından daha düşük olduğunu düşündükleri için itiraz etmektedirler. Okulların eğitim ücretlerinde yüksek düzeydeki indirim yapmas1, gelirlerinin önemli bir kısmından feragat etmesi anlamına gelmektedir. Bu durum maliyetlerin düşmesine, öğretmenlerin işlerini kaybetmesine, özel okulların gelecekteki yatıım planlarında kesintilere yol açan nakit akışının azalmasına ve buna bağlı olarak özellikle düşük ücretli özel okulların sunduğu hizmet kalitesinde düşüşe neden olabilir. Benzer şekilde Öztürk tarafindan salgın öncesinde yapılan bir analizde (2018) özellikle Anadolu'daki şehirlerde öğrenci bulma sorunu yaşayan kurumların indirimlere gitmeleri kârlılıkları üzerinde bask1 yaratabileceği ifade edilmektedir. 
Özel okul velilerinin, COVID-19 salg1nı süresince özel okullarda karşılanmayan hizmetlere ilişkin özel okulların ücret iadesi politikaları ile ilgili görüşleri Tablo5'te verilmiştir.

Tablo 5. COVID-19 Salgın Süresince Özel Okullarda Karşılanmayan Hizmetlere İliskein Özel Okullarm Ücret İadesi Politikalar

\begin{tabular}{|c|c|c|c|c|}
\hline & \multicolumn{2}{|l|}{ Değişken } & \multirow{2}{*}{$\frac{n}{139}$} & \multirow{2}{*}{$\frac{\%}{\% 97}$} \\
\hline \multirow{4}{*}{$\begin{array}{l}\text { Velilerin öğrenim ücretlerinde indirim } \\
\text { beklentisi }\end{array}$} & \multirow{4}{*}{$\begin{array}{l}\text { Uzaktan eğitim süresince öğrenim ücretlerinde } \\
\text { indirim beklentisi } \\
\text { Harmanlanmış öğrenme modelleri uygulanırsa, } \\
\text { öğrenim ücretlerinde indirim beklentisi }\end{array}$} & Evet & & \\
\hline & & Hayır & 4 & $\% 3$ \\
\hline & & Evet & 133 & $\% 93$ \\
\hline & & Hayır & 10 & $\% 7$ \\
\hline Kategori & Kod & & & \\
\hline \multirow{3}{*}{$\begin{array}{l}\text { Velilerin servis ve yemekhane } \\
\text { hizmetlerine yönelik ücret iadesi için } \\
\text { başvurdukları yollar }\end{array}$} & Okula başvuru & & 92 & 64 \\
\hline & Tüketici hakem heyetine başvuru & & 11 & 8 \\
\hline & Başvuruda bulunmadım & & 40 & 28 \\
\hline \multirow{2}{*}{$\begin{array}{l}\text { Velilerin salgın süresince özel } \\
\text { okulların ücret politikası ile ilgili etik } \\
\text { dışı uygulamalarıyla karşılaşma } \\
\text { durumları }\end{array}$} & Etik dışı uygulamalarla karşılaştım. & & 59 & $\% 40,1$ \\
\hline & Etik dışı uygulama ile karşılaşmadım. & & 94 & $\% 59,9$ \\
\hline \multirow{4}{*}{$\begin{array}{l}\text { Salgın süresince özel okulların ücret } \\
\text { politikası ile ilgili etik dışı } \\
\text { uygulamaları }\end{array}$} & Yemek ve servis ücretinin peşin olarak alınması & & 43 & $\% 30$ \\
\hline & $\begin{array}{l}\text { Ücret iadesi sürecinde okul lehine kararlar } \\
\text { alınması }\end{array}$ & & 30 & $\% 20,1$ \\
\hline & $\begin{array}{l}\text { Kitap ücretinin olması gerektiğinden fazla } \\
\text { olması }\end{array}$ & & 28 & $\% 19,6$ \\
\hline & $\begin{array}{l}\text { Öğretmenlerin işine son verilmesi ve eğitimin } \\
\text { sekteye uğratılması }\end{array}$ & & 3 & $\% 2,1$ \\
\hline
\end{tabular}

Özel okullar karşılanmayan servis ve yemekhane hizmetlerine ilişkin ücret iadesi yapacaklarını duyurmuşlardır. Tablo 5'te görüldüğü gibi katılımcıların \%64'ü karşılanmayan servis ve yemekhane hizmetlerine ilişkin ücret iadesi için okula, \%8'i tüketici hakem heyetine başvurduğunu \%28’i ise herhangi bir başvuruda bulunmadığını belirtmişlerdir. Okulların fiziksel olarak kapalı kaldığı süre boyunca karşılanmayan servis ve yemekhane hizmetlerine ilişkin velilerin \%17'si ücret iadesinin tamamını, \%43' ü ise bir kısmını alabilmiştir. Özel okul velilerinin \%29'u hiç ücret iadesi alamazken, \%11'i ücret iadesi ile ilgili sürecin devam ettiğini ifade etmiştir. Ankete katılan veliler, ücret iadesinin yöntemi, ücret iadesinin süresi ve ücret iadesinin oranı konularında rahatsızlık duyduklarını belirtmişlerdir. Bu durum, özellikle ailelerin gelir kaybına uğradığ1 bir dönemde, velilerin haklarını korumak için özel okullarla ilgili denetlemelerin daha sikı olmasinı gerektirmektedir.

Katılımcıların \%40’1 salgın süresince özel okulların ücret politikası ile ilgili etik dışı uygulamalarıyla karşılaştıklarını belirtmektedirler. Katılımcılar bu etik dışı uygulamaları: velinin isteğine bağlı hizmetlerin zorunlu tutulması, ücret iadesinde okul lehine kararlar alınması, kitap ücretinin gerektiğinden fazla olması ve öğretmenlerin işine son verilerek eğitimin sekteye uğratılması olarak tanımlamaktadırlar.

Milli Eğitim Bakanlı̆̆1, 2019-2020 eğitim öğretim döneminden itibaren özel okulların öğrenci kayıt sözleşmesinde güncelleme yapılmasını sağlamıştır. Güncellenen öğrenci kayıt sözleşmelerinde yemek, kahvaltı, takviye kursu, yatakhane, kitap, kırtasiye, servis ve etüt ücreti veli isteğine bağlı hizmetler olarak yer almıştır (https://ookgm.meb.gov.tr/www/ogrenci-kayıt-sozlesmesi/icerik/1423). Buna karşın katılımcılar özel okullar tarafindan yemek, kitap ve kırtasiye hizmeti almaya zorlandıklarını ifade etmişlerdir. "Yönetmeliğe aykur biçimde yemek hizmeti almaya zorlandım, yemek hizmetini almadan asla kayıt yapılmayacă̆z söylendi." K:17, "Kitap ve yemek servis konusunda yönetmelikte zorlama olamaz diyor, zorlama var. 21Eylül' de parasın ödediğim halde çevrimiçi derslere almmayacă̆ımı;. Sebebi 4000 TL'lik kitap kolisi almamıs olmamr:" K:19. "Özel Eğitim Kurumlar Yönetmelĭ̈indeki Değişikliğe Dair Yönetmelikete yemek, kiyafet ve kitap velinin talebine bağhdır, der. Ancak okulumuz yemek ve kitabı diretmeye devam ediyor. Bu kanuna karsı gelmektir." K:56. Milli Eğitim Bakanlığ1 bu konuda Özel Okul Dernekleri Temsilci Başkanlarının, uzaktan eğitim sürecinde yemek ve servis ücreti alınmayacağı konusunda yaptığı basın açıklamasına da dikkat çekmektedir (http://ookgm.meb.gov.tr/www/sss.php ). Bu açıklamalara rağmen katılımcılar, özel okulların isteğe bağlı hizmetleri almayan öğrencilerinin çevrimiçi eğitimden faydalanmasını engellediğini ifade etmektedirler. "Kaynt yenileyebilmek için kayıt esnasında yemek parasımn alınmasın zorunlu tutuyorlar, secme hake. tanınmyor! Kitap listesinde seçme hake. tanımmadiğ gibi alınmazsa çocuğun eğitim hakk.mın engelleneceği mesajlar atıliyor velilere! Cevrimiçi 
eğitim sifrelerinin verilmeyeceği ifade ediliyor!..” K:59. Katılımcılar aynı zamanda kitap ücretinin olmas1 gerekenden daha fazla olduğunu ve bu uygulamayı etik dışı bulduklarını belirtmişlerdir. "Kitap kutusunun içerisine 375 adet cerrabi maske konulmuss. Gidilmeyen okul takılmayan maske parasi. Veli den nasil para alabilirim. Hiç etik değil." K:150. "Kitap kolisi bažrllyorlar ancak hepsine toplu bir fiyat çıarryorlar. Neye be kadar ödediğimiži bilmiyoruz:" K:93.

Milli Eğitim Bakanllğ1 Özel Öğretim Kurumlar1 Yönetmeliğinin 56. maddesi hükümlerince; "eğitim ve öğretim yılı başlamadan kurumdan ayrılanlara, öğrencinin ödeyeceği yıllık ücretin \%10 dışındaki kısmı, eğitim ve öğretim yllı başladıktan sonra kurumdan ayrilanlara ise öğrencinin ödeyeceği yılllk ücretin \%10’u ile öğrenim gördüğg̈ günlere göre hesaplanan miktarın dışındaki kısmı öğrenci velisine/vasisine iade edilir. Öğretime başladıktan sonra ayrılan öğrencilerden alınacak ücret kurumun öğrenim ücretinden fazla olamaz." Katılımcıların etik dışı olarak tanımladıkları ücret iadesi oranına ilişkin ifadelerinin, 56. Madde hükümleri çerçevesinde gerçekleşen \%10'luk yasal kesintinin mücbir sebepler çerçevesinde ele alınarak yapılmamasına yönelik talepleri olduğu anlaşılmaktadır. "Pandemi sürecinde öğrencinin kaydr almorsa \%10'luk kesinti olmamal.” K:33. Katılımcıların aynı zamanda ücret iadelerinin gerçekleştirilme yöntemi ve süresiyle ilgili sıkıntılar yaşadığ görülmektedir. "Kayıt ücretinden \%10 kesinti yapılacak olması ve iadenin 2-3 ay gibi uথunca bir süre yapılmaması!" K:54. Katılımcıların etik dışı olarak tanımladıkları ücret iadesi oranına ilişkin ifadelerinin, 56. Madde hükümleri çerçevesinde gerçekleșen \%10'luk yasal kesintiyi de kapsayacak șekilde yasal olmayan kesintileri de kapsamaktadır. Velilerin bu kesintileri etik dışı bulmasındaki ana kaynak yine sözleşmelerde yer alan mücbir sebep maddesi olarak görülmektedir. Veliler, mücbir sebep maddelerine dayanarak, bu kesintilerden muaf olmak istediklerini ifade etmektedirler. "Mücbir sebep maddeleri yalnız̨ca okulu korumuyor aslinda ama okullar kendi işine geldiğg gibi işletijor bu maddeleri." K:141. "...Aynca imzaladiğmmz. sözleşme yüz yüze eğitime göre düzenlenmesinin yan sira mücbir sebepler maddesi kaldınlmışt ki bence biç etik değil. Bu durumda kesintili talep ettigimiz iadeleri almann da önü kapanyor. Mecburen imzaladı..” K:37.

Bu konulardan hareketle, Bulut (2020, 14 Mayıs), özel okulların, örgün eğitim dışında aldıkları ücretleri ifa edemeyecekleri anlaşılmışsa ve telafisi de mümkün değilse iade etmesi hususunda görüş belirtildiğini ifade etmiştir. Bu ücretler, öğrenim ücreti -telafi eğitim yapılmaması durumunda-, takviye kurs ücreti, etüt ücreti, yemek, servis ve yatakhane ücreti olup, ifa imkânsızlı̆̆1 nedeniyle, iade edilmelidir. Ankete katılan velilerin neredeyse tamamı $(\mathrm{f}=139)$ salgın süresince özel okulların kapalı olması ve uzaktan eğitime devam etmesi durumunda öğrenim ücretlerinde indirim yapılmasını beklemektedir. Bu durum yüz yüze yapılan geleneksel öğretim yöntemleri ile teknoloji tabanlı öğretim yöntemlerinin birleştirilmesi olarak adlandırllan (Gülbahar, 2009) harmanlanmış öğrenme (blended learning, hybrid learning) modelinin uygulanması durumunda da benzer olup, velilerin \%90'1ndan fazlası $(\mathrm{f}=133$ ) yine öğrenim ücretlerinde iade yapilmasinı talep etmektedir.

\section{COVID-19 Salgını Süresince Özel Okullara Devlet Desteği ve Özel Okulların Giderlerinde Azalma}

COVID-19 salgını süresince özel okulların giderlerinde azalma yaşanmış ve aynı zamanda özel okullar çeşitli devlet desteğinden faydalanmışlardır. Bir özel öğretim kurumunun, sermaye ve yatırım giderleri haricinde gider kalemleri -pazarlama-satış giderleri elektrik su yakıt (ısınma-aidat) mali müşavir ücreti hukuk müşaviri ücreti, telefon/internet kırtasiye giderleri, ambalaj-paketleme giderleri, sigorta giderleri, nakliye gideri bakım-onarım genel giderler, beklenmeyen giderler olmak üzere ifade edilebilir (Oran Kalkınma Ajansı, 2016:24). Salgnn ile birlikte, elektrik, su, kırtasiye giderleri, ambalaj ve paketleme giderlerinde büyük oranda düşüş olduğu görülmektedir. Bu düşüş, toplam giderin $\% 1,5-2$ ' sine karş1l1k gelmektedir. Buna ek olarak uzaktan eğitime dahil edilmesi zor olan bazı branş öğretmenlerinin işten çıkarılmasının önüne geçmek amacıyla kısa çalışma ödeneği kullanımının önü açılmıştır. Kısa çalışma ödeneği alan bir öğretmenin maaşında yaklaşık \%40 oranında düşüş yaşanmıştır (Seçkinler Grup, 2020). Özel öğretim kurumlarında çalışan öğretmenlerin kısa çalışma ödeneğinden faydalanma oranlarına ilişkin yapılmış bir çalışmaya rastlanmamıştır. Bu oranın \%20 olduğu düşünüldüğünde bir özel öğretim kurumunun giderlerinde en az \%15-20 oranında bir düşüş yaşandığı belirtilebilir.

Personel maaş giderlerinde azalma: Salgın döneminde özel okullar, personel maaşlanı için 7244 Sayılı Yasa'nın 8.maddesine göre genişletilen kısa çalışma ödeneğinden faydalanabilmişlerdir. Kısa çalışma ödeneği, işyerindeki çalışma sürelerinin geçici olarak azaltılması veya durdurulması durumunda istihdamın korunmasını sağlama amacını taşımaktadır (işkur.gov.tr). 4447 sayılı İşsizlik Sigortası Kanunu'nun ek 2. maddesi ile geçici 23. maddesinde belirtilen esaslar çerçevesinde, işyerlerinde çalışan personellerin kısa çalışma ödeneğinden faydalanabilmesi için şu kriterler aranmıştır: 
-Salgın nedeniyle işyerindeki haftalık çalışma sürelerini geçici olarak $1 / 3$ oranında azaltan veya faaliyetlerini tamamen veya kısmen -en az dört hafta süreyle- durduran işverenler kısa çalışma ödeneğine başvurabilir.

-Kısa çalışma ödeneğinden faydalanmak için haftalık çalışma süresinin 1/3' ü oranında azaltılması ile ilgili olarak, 4857 sayılı İş Kanununun 63'üncü maddesi uyarınca çalışma süresinin haftada en çok 45 saat olabileceği bilgisinden hareketle işyerinde çalışma süresinin haftalık 30 saat veya aşağısında olması gerekmektedir. Bu durum özel öğretim kurumlarında çalışan öğretmenler açısından farklılaşmaktadır. Çalışma ve Sosyal Güvenlik Bakanlığı İş Teftiş Kurulu Başkanlığ1 "Özel Öğretim Kurumlarında Çalışan İşçilerin Çalışma Koşullarının İyileştirilmesi" başıklı teftiş raporunda, "Öğretim personelinin çalışma süresinin belirlenmesinde işyeri uygulaması esas alınarak, sözleşmede belirlenen ders saati ve ek ders saati ile okuldaki ders dışı faaliyetlere ilişkin toplam süre dikkate alınacaktır. İş sözleşmesinde, çalışma süresine ilişkin herhangi bir hüküm yok ise işyeri uygulamaları da dikkate alınarak (ders dışı faaliyetler ve benzeri çalışmaların olmaması halinde) haftalık ders saatinin, aynı zamanda çalışma süresi olduğu kabul edilmelidir.” denilmektedir (T.C. ÇSGB, 2015). Bu doğrultuda, özel öğretim kurumlarında çalışan öğretmenlerin kısa çalışma ödeneğinden faydalanabilmesi için ders saatlerinde $1 / 3$ oranında azalma yaşanmalıdır.

-Kısa çalışmaya tabi tutulan işçilerden kısa çalışma başlama tarihinden önceki 60 gün hizmet akdine tabi olmalıdır.

•Kısa çalışmaya tabi tutulan işçiler, son 3 yılda 450 gün süreyle prim ödemiş olmalıdır.

Özel okullarda çalışan öğretmenler ve diğer personeller kısa çalışma ödeneğinden faydalanabilmiştir. Bu ödenek ile, özellikle uzaktan eğitim yoluyla verilmesi mümkün olmayan ya da kısmen mümkün olan branş öğretmenlerinin işten çıkarma ile karşı karşıya kalmasının önüne geçilmiştir. Bununla birlikte, kısa çalışma ödeneği ile geçinmek zorunda kalan çalışanlar, okul kapanmasından bu yana çok büyük bir gelir kaybına uğramıştır. Son 12 aylık prime esas kazançların aylık ortalaması 4000 TL (brüt) olan bir çalışana 2.381,78 TL (brüt) kısa çalışma ödeneği ödenmiştir (Seçkinler Grup, 2020). Bu özel öğretim kurumlarında çalışan personelin gelirlerinde yaklaşık olarak \%40 oranında bir düşüş yaşandığını göstermektedir. $\mathrm{Bu}$ çalışanlar, uzaktan eğitim nedeniyle şehir değiştirmiş olabilir ya da gelir kaybı nedeniyle başka iş arayışına girmiş olabilirler. Buna karşın uzaktan eğitimin eksiksiz sürdürüldüğü özel okullar, uzaktan eğitim yoluyla tam mesai çalışan personelini kısa çalışma ödeneğinden faydalandırmış mıdır? Özel öğretim kurumlarında çalışan personellerin yüzde kaçı bu ödenekten faydalanmaktadır? Bu konu ile ilgili yayımlanmış resmi bir belge bulunmasa da, özel öğretim kurumları kurucuları ve yöneticileri tarafından kısa çalışma ödeneğinin istismar edildiğine ilişkin birçok haber yapılmıştır (Barskanmay, A., 2020, 13 Mayıs; Kamudan Haber, 2020, 6 Eylül). Ankete katılan veliler, özel okulların kısa çalışma ödeneğinden faydalandıklarını ve bu faydanın velilere ücret iadesi yapılmaması ile birleştirildiğinde haksız kazanç olarak görüldüğünü

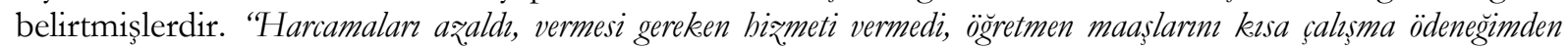
karşıladı ve bizden tam para aldr. Bunun yannda servis ve yemek ücretlerinde bile baksız, ve çok yükesek kesintiler yaptr." "...Okul kapal olsa da personel giderlerinin devam ettiğini, mutfăga malzeme aldlklarm, elektrik, su, doğalgaz ödemeye

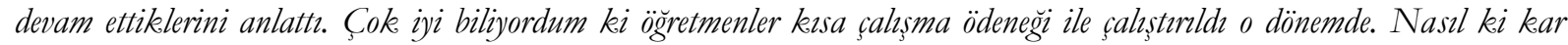
ortağmi değiliz, herkes zor durumda kald, verilmeyen hizmetin ücretinin bir kısmm keserek geri ödeyemezsiniz" "Gelirimizi azald ya da tamamen kaybettik. Cevrimiçi eğitimle pek, çok kalemden tasarruflar oluyor, veliye yansitmalular, karllhklarm da olağanüstü şartlara göre azaltmallar. Oysa biç düsünmeden normal zamlarm da yaptılar. Bizlerden bizmetlerinin karşılğgm alırken, kess çalısma ödeneğinden bangi nedenle faydalandıklarm da anlamiyorum” K:102. Özel ögretim kurumlarındaki temizlik personelleri, güvenlik görevlileri ve büro personelinin kısa çalışma ödeneğinden faydalanması olağan görülse de, eğitim faaliyeti uzaktan eğitim yoluyla devam ettiğine göre öğretmenlerin çalışmaya devam etmesi nedeniyle kısa çalışma ödeneğinden faydalandırılması olağan dışı görülmektedir. Bu durum hem veliyi, hem personeli hem de devleti gelir kaybına uğratan etik dışı bir uygulamadır.

Elektrik, su ve 1sınma giderlerinde azalma: COVID-19 salgını süresince özel okulların, elektrik, su, kırtasiye giderleri, ambalaj ve paketleme giderlerinde büyük oranda düşüş olduğu görülmektedir. Bu düşüş, toplam giderin \% 1,5-2' sine karşıllk gelmektedir (Oran Kalkınma Ajans1, 2016).

Servis ve yemek giderlerinde azalma: COVID-19 salgını süresince özel okulların, servis ve yemek gelirinde azalma yaşamıştır. Diğer taraftan veliler almadıkları bu hizmet için ücret iadesi talep etmektedirler. 
İlan, reklam ve çevre temizlik vergilerinde azalma: Özel okullar, 7244 sayıll kanunun 1/G.Maddesi ile; "Faaliyetleri durdurulan veya faaliyette bulunamayan işletmelerin y1llk ilan ve reklam vergileri ile ylllk çevre temizlik vergilerinin, faaliyetleri durdurulan veya faaliyette bulunulamayan dönemlere isabet eden kısmı alınmaz." şeklindeki düzenlemeden faydalanabilmektedir.

Kira giderlerinde erteleme: Özel okullar, 7226 Sayılı Bazı Kanunlarda Değişiklik Yapılmasına Dair Kanun'nun Geçici Madde 2.maddesi ile; "1/3/2020 tarihinden 30/6/2020 tarihine kadar işleyecek iş yeri kira bedelinin ödenememesi kira sözleşmesinin feshi ve tahliye sebebi oluşturmaz." şeklindeki düzenlemeden faydalanabilmektedir.

\section{Tartışma, Sonuç ve Öneriler}

Son yıllarda özel okulların eğitim sistemi içindeki payı giderek artmıştır. Bu durumun başlıca nedenleri arasında; yabancı dil eğitimi, sınıf mevcutlarının azlı̆̆ı, kullanışı okul binaları, teknoloji kullanımı, alanlarında uzman öğretmenler, etkin rehberlik, klasik araç gereç dışına çıkılması, ağır çanta taşıma zorunluluğunun olmaması, laboratuvarların etkin kullanımı, sosyal ve sanatsal faaliyetlerin yoğun olması, okuldaki etkinliklere öğrenci ve velilerin aktif katılımının sağlanması sayılabilir. Özel okulların COVID-19 salgını surecinde hizmet ve ücret politikaları hakkında velilerin görüşlerini almayı hedefleyen bu araştırmada özel öğretim kurumları velilerinin, hanehalkının özel okul eğitimi harcamaları, özel okullarda öğrenci kayıt sözleşmelerinin durumu, özel okullara öğrenci kayıtları, özel okullarda karşılanmayan hizmetler ve bu hizmetlere ilişkin özel okulların ücret iadesi politikaları, özel okullara devlet desteği ve özel okulların giderlerinde azalma temaları ortaya konulmuştur.

COVID-19 salgm süresince banebalkinn özel okul eğitimi harcamalar temasinda; Türkiye'de hanehalklar1 tarafından yapılan eğitim harcamaları diğer ülkelere oranla yüksektir, 2020 yılında eğitim sektörü harcamalarında büyük bir düşüş yaşanması şüphesiz ki salgın döneminde yaşanan ekonomik durgunluk ve hanehalklarının gelir düzeyinde yaşanan düşüş ile ilişsilidir. Araştırma sonucunda salgın sürecinde velilerin hanehalkı gelirinde düşüş yaşandığı bulunmuştur. Ailelerin gelir kaybındaki düşüşs sadece Türkiye’ de değil tüm dünya ülkelerinde gerçekleşen bir durumdur. Bu durum; Gonzalez, Karpman, Kenney ve Zuckerman (2020)tarafindan "Salgun yü̈̈̈̈nden baz̨lar endişeli aileler gelir kaynaklarm kaybedecek ve ögrenciler okullarnna ödeme yapma konusunda ücretlerde zorluk yaşayacaklar ." şeklinde belirtilmiştir.

Velilerin tamamına yakını özel okul ücretlerini yüksek olduğunu belirtmişlerdir. Özellikle de yemek, kırtasiye ve kitap ücretlerinin fazla olması, çevrimiçi eğitim ile yüz yüze eğitim ücretlerinin aynı olması (yani çevrimiçi eğitimin yüz yüze eğitime denk tutulması), ücretlerin kanunda belirtilen artıştan daha fazla olduğu belirtilmiştir. Okullarda eğitime ara verilen sürede uygulanan uzaktan eğitimle ilgili olarak Talim ve Terbije Kurulu Baskeanliğmm 06.05.2020 taribli ve E.6790450 saynl yažsinda özel okullarda verilen eğitimin telafi eğitimiyle birlikte yüz yüze eğitime denk olduğu belirtilmiştir. Yapılan araştırmalarda yüz yüze eğitimdeki verimliliğin, uzaktan eğitimle verilen eğitimle aynı olmadığ ortaya konulmuştur. Bahçeşehir Üniversitesi(2020) tarafindan yapılan araştırmada yüz yüze eğitimden tarafların memnun olmadığı, ayrıca TEDMEM (2020) tarafindan yapılan araştırmada ise özellikle küçük sınıflarda yüz yüze eğitimin daha verimli olduğu ve yüz yüze eğitimin öneminin altı çizilmiştir. Belki özel okullar bu dönemde eşzamanlı ve eşzamansız olarak müfredatı bitirmiş olabilirler fakat daha nitelikli bir eğitim için çocuklarını özel okullara gönderen velilerin beklentilerine cevap verip veremedikleri başka bir araştırma problemidir

Yüz yüze eğitimin bir gününün uzaktan eğitim ile karşılaştırlması mümkün değildir. Bir günlük yüz yüze eğitim bir günlük uzaktan eğitimden her bakımdan değerlidir(Zhou,2020). Kanada 'da yükseköğretim kurumları için Kanada Acil Müdahale Yardımı Kurumu’nun (CERB) tavsiyeleri şöyledir: Bazı öğrenci ücretlerinden ve geç kayıt için cezalardan feragat edilmeli, öğrencilerin başvurabilecekleri özel bir burs oluşturmalı, ödeme süreleri uzatılmalı, okuldan ayrılan öğrenciler için ödeme planı programı genişletilmeli ve daha uygun maliyetli bir çevrimiçi ödeme sistemi kurulmalıdır (Daniel, 2020). Yine Dubai'de COVID19 sebebiyle ekonomik olarak sıkıntıya giren 13.900 kişi, ebeveynlerin \%50'ye varan son maaş kesintileri ve yüksek yaşam maliyetleri arasında bu fonları sağlamakta zorlandığı için okul ücretlerini \%30 azaltmak için bir dilekçe imzalamışlardır (Nicola vd., 2020). Hindistan'da aileler özel okulların ücret artışlarını sorgulamışlardır. Eyaletler arasında farklılıklar olmasına rağmen özel okullarla ilgili çeşitli kararlar alınmıştır. İnsan Kaynakları Geliştirme Bakanı; özel okullardan yıllık ücret artışlarını yeniden gözden geçirmelerini istemiştir. Bazı eyaletlerin yüksek mahkemeleri özel okulların Gujarat, Maharashtra ve Odisha da dâhil olmak üzere en az dokuz eyalet, üç aylık ücretlerin ertelenmesine izin vermişler, diğerleri, özel olarak öğrenim altında olanlar hariç diğer ücretlerden feragat etmişlerdir (Mandhanı, 2020). Kenya'da 
2020 ikinci ve üçüncü dönem ücretlerinin okullar tarafindan ailelere geri ödenmesi talimatı verilmiştir (Mbogo, 2020). Yapılan başka bir araştırma da ise Uganda'daki e-öğrenme programlarına yapilan yüksek yatırım düzeyine rağmen, düşük bir benimsenme oranı olduğu bulunmuştur. Benimseme düzeyini artırmak için yapılması gerekenler arasında; fon kaynaklarını genişletmek, fon kaynakları için koordinasyon mekanizmaları sağlamak, uygun fiyatlı okul ücretleri yapısı geliştirmek ve uygun bir ücret ödeme sistemi geliştirmek olduğu belirtilmiştir (Bigirwa, Ndawula ve Naluwemba, 2020). Bütün bunların dışında UNICEF'in (2020) okulların yeniden açılmasında "devletlere okul harclarm ve diğer masrafları (okul üniforması, vs.) almayın ve okula yeniden kayıt oranlarm artırmak için okula kabulün önündeki diğer engelleri kaldrrn" tavsiyesinde bulunmuştur. Ebola salgınında Sierra Leone hükümeti sınav ücretlerinden feragat etmiş ve ortaokula mali destek ile iki ylllk ücretleri ödemiştir (World Bank, 2015).

Özel okul ücretlerinde yapılan artş, okullarn ara simflarmnn eğitim ücreti bir önceki e ğitim-ögretim ynlanda ilan edilen, okulda devam eden ögrencilerin ürreti ise ögrenci kaynt sözleşmesinde belirlenen eğitim ücretine (Ek ibare: RG19/2/2020-31044) bir önceki ynlin ortalama (Y.İ-ÜFE+TÜFE)/2 oranma en fąla \% 5 orannda artıs yapularak belirlenir. Velilerin özel okul ücretlerini fazla bulmaları, özel okulların bu maddeye dikkat ederek artış yapmadıkları anlamına gelebilir. Dünya da özel okullarda COVID 19 nedeniyle yaşanan ekonomik kayıplar nedeniyle özel okulların nasıl planlama yapması gerektiği ile ilgili olarak birçok ülkede özel okullara öneriler bulunmaktadır. Avusturalya da bazı özel okullar öğrenci kaybının önüne geçmek için ücretlerinde indirim, ücretlerini ödeyemeyen aileler yardım, eğitim borçlanını erteleme yönüne gitmişlerdir (Kidson, 2020). 20202021 eğitim öğretim yllına öğrenciler okullara daha farklı fiziksel ve duygusal ihtiyaçlarla döneceklerdir. Bunun için okulların yeni okul modellerine yönelmesi gerekebilir (Zhou, 2020). Bu süreçte birçok özel okulun öğrenci kaybı yaşadığı bir gerçektir. Fakat bu kaybı her şeye rağmen okulunu birakmayan velilerden telafi etmeye çalışmak da etik açıdan doğru bir yaklaşım tarzı değildir. Ayrıca, salgın sürecinde velilerin de gelirlerinde büyük kayıplar yaşanmıstır.

COVID-19 salgin süresince özel okul ögrenci kayıt sözlesmelerinin durumu temasinda; velilerin yarısından fazlası kayıt sözleşmelerini okuyup anlayarak imzalamadıklarını belirtmişlerdir. Veliler, kayıt sözleşmelerinde özellikle yemek ve kitap ücretinin yasal olmamasına rağmen zorunlu tutulmasından, çevrimiçi eğitim ücretine yönelik maddelerin bulunmamasından rahatsızlı duyduklarını belirtmişlerdir. Ek:RG-19/2/2020-31044) Kurumlar, ögrenci veya kursiyerlerden; yemek, kabvalt, servis, pansiyon/yatakhane, kitapkurtasiye, kiyafet, etüt ve benzeri hižmetler karşzligunda alacaklar ü̈retleri mayıs aymm sonuna kadar aynca tespit ederler. Bu fikrada yer alan bizmetlerden, talep eden veliler faydalanır. MEB, kitap ve yemek gibi hizmetleri tamamen veli isteğine bırakmıştır. Oysaki bazı özel okullar kitap ve yemeğe katıllımı velilere zorunlu tutmuştur.

COVID-19 salgm süresince özel okullara ögrenci kayntlar temasinda; velilerin tamamina yakını nitelikli eğitim öğretim için özel okulları tercih ettiklerini belirtmişlerdir. Ayrıca veliler; okulun uzaktan eğitim sürecindeki başarısı, dil eğitimi, temizlik ve hijyen, iletişim, okuldan geçen sürenin uzun olması/çalışan anne-baba olmak, sosyal faaliyetler, rehberlik hizmetleri, çocuğun 1srarı, devamlılığı sağlamak ve güvenlik nedeni ile özel okulu tercih etmektedirler. Bu bulgular Nartgün ve Kaya'nın 2016 yllında yaptıkları araştırma bulgularıyla da örtüşmektedir. Araştırmada, "Velilerin Okuldan Beklentilerì" başlıklı madde incelendiğinde, veliler, öncelikle çocuklarının mutlu olduğu ve kişiliğini gelişimine katkıda bulunan bir okul istemektedirler. Daha sonra ilk sırada yabanc1 dil eğitimine verdiği önem ile fiziksel güvenliğinin sağlanmasının önemli olduğu belirtilmiştir. Bunlarla birlikte okulun sahip olduğu sosyal imkânların (kulüpler, sportif ve sanatsal faaliyetler, uluslararası projeler vb.) çocuğu hayata hazırlamada önemli olduğu, okullarda verilen kahvaltılar ile öğle yemeklerinin sağlıklı olmasının ve hijyenik şartlarda bir okul ortamı sağlanmasının önemli olduğunun altını çizmişlerdir. Verilen görüşlerle örtüşen diğer bir araştırmada ise; özel okulda ve devlet okulunda çalışan öğretmenlerin, devlet okulu ile özel okul arasında sınıf yönetimi anlayışı farklılı̆̆ bulunduğu, devlet okullarında daha otokrat-özelde daha demokrat bir sınıf yönetimi anlayışını tercih edildiğini, özelde profesyonel yardım ve PDR desteği alma imkânının daha fazla olduğu sonucuna ulaşılmışıtı (Ilgar, 2014). Bu sonuçlar ışı̆̆ında devlet okullarını da geliştirebilirsek, eğitimin niteliği artabilir. Özel okulların tercih edilmesinde rol oynayan bu etmenlerin uzaktan eğitim sürecinde çevrimiçi yapılan eğitimde ne ölçüde etkili olduğunun da sorgulanması gerekmektedir. Çünkü bazı özel okulların İngilizce ders saatlerini düşürdükleri ve yüz yüze eğitimde 40 dakika olan ders saati süresinin çevrimiçi eğitimde 30 dakikaya düşürüldügü bilinmektedir. Salgin süresince özel okulları devlet okullarından ayıran özellikleri, şartlar nedeniyle özel okullar yerine getirememiştir. Ayrıca, velilerin maddi kayıplar yaşaması, öğrenim ve yemek ücretlerinde beklenen indirimlerin yapılmaması nedeniyle özel okullar öğrenci kayıtlarında düşüşler yaşamıştır. Öğrenci kayıtlarında yaşanan düşüşler yani devlet okullarına doğru yaşanan öğrenci kaymaları, devlet okullarında var olan sorunların artması ve özel okulların kapanması anlamina gelmektedir. 
COVID-19 salgm süresince özul okullarda karşılanmayan hiz̧metler ve bu biz̧metlere ilişkin özel okullarn ücret iadesi politikalar temasında; özel okulların eğitim hizmetinden velilerin çoğunluğu faydalandıklarını, rehberlik hizmetlerinden velilerin yarıya yakını faydalanamadığını, velilerin yarısından fazlası ise kısmen faydalandığını belirtmiştir. Ölçme ve değerlendirme hizmetlerinden velilerin yarısı kısmen faydalandıklarını belirtmişlerdir. Araştırmaya katılan veliler; yemekhane ve servis hizmetlerinden hiç faydalanmadıklarını belirtmişlerdir. Revir, sanatsal etkinlikler, sportif faaliyetler, kütüphane ve laboratuvarlardan ise velilerin tamamına yakını faydalanmadıklarını belirtmişlerdir.

Özel okullarda karşılanmayan hizmetler ve bu hizmetlere ilişkin özel okulların ücret iadesi politikaları; karşılanmayan hizmetlerin ücret iadesi için velilerin yarısından fazlası okula başvurarak ücret iadesi talebi istediklerini, yarıya yakını ise herhangi bir başvuru yapmadıklarını belirtmişlerdir. Karşılanmayan hizmetlerin ücret iadesinin tamamını alan katılımcı sayısı çok azdır. Ücretlerin bir kısmını alan katılımc1 sayısı yarıdan fazladır. Hiç ücret almayan katılımcı sayısı yarıya yakınıdır. Araştırmaya katılan velilerin yarısından fazlası, ücret iadesini genellikle bir sonraki eğitim öğretim yılından düşerek almayı tercih etmişlerdir. Velilerin çoğu ücret iadesini uzak tarihli bir takvime göre almışlardır. Başvuruya gerek kalmadan ücret iadesi alan veli sayısı oldukça azdır. Ücret iadesinin tamamını alan veli sayısı oldukça sınırlı sayıdadır. Velilerin yarısından fazlası ücret iadesi taleplerini kısmen gerçekleştirildiğini, yarıya yakın veli de ücret iadesinin gerçekleştirilemediğini belirtmiştir. Yukarıdaki sonuçlara göre özel okulların bir kısmı verilmeyen hizmetlerin ücretini veli başvurusuna gerek kalmadan veliye iade etme yoluna gitmiştir. Ücret iadesinin yapılmasını 07.04.2020 tarih ve 6215860 Esas sayılı MEB Özel Öğretim Kurumları Genel Müdürlüğü’nün “Korona Virüs Tatili ve Özel Kurumların Ücretleri” başliklı yazısında “...kurucu ve veli/kursiyer arasinda anlasmaya varlarak düzenlenen sözlesmeler, usulüne uygun olarak düzenlenip imza edilmislerse resmi nitelikli bukuki değeri olan belge niteliğinde olup karşıllkh taabbütlerin yerine getirilmesi bukuken zorunluluk arz. etmektedir. Cesitli olağanüstü sebeplerle verilemeyen hizmetlerin ileri bir taribte telafisinin yapulmasi, telafisinin

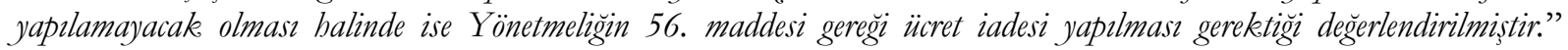
şeklinde görüş bildirmiştir. Bu görüşe göre özel okullar veremedikleri hizmetlerin bedelini veliye geri ödemek zorundadır. Türkiye Ö́zel Okullar Derneğinin 13.05.2020 tarihli aşağıda verilen kamuoyu duyurusunda "Eğitim dernekleri olarak bu süreçte okullarn açı olamayısından kaynakl ögrencilerimize sunulamayan

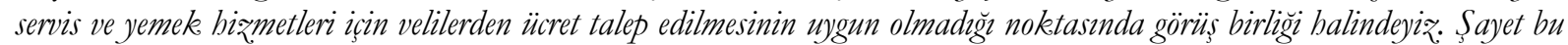
ürretler velilerimiz tarafindan peşin veya herhangi sekilde ödenmis ise mubtemel telafi eğitimi sonrasi, dönem başında hesaplanarak iade veya mahsup edileceğini kamuoyuna saygzyla duyururuz:" servis ve yemek ücretlerinin geri ödeneceği belirtilmiştir (Türkiye Özel Okullar Dergisi, 2020). Fakat ekim ayında bile bazı özel okullarda ödemelerini alamadıklarını belirten veliler bulunmaktadır.

COVID-19 salgm süresince özel okullara devlet desteği ve özel okullarm giderlerinde azalma temasinda; COVID19 salgını süresince özel okulların giderlerinde azalma olmuş ve aynı zamanda özel okullar çeşitli devlet desteğinden faydalanmışlardır. Ayrıca özel okullar kira giderlerini ve reklam vergilerini erteleme olanaklarından da faydalanmışlardır. Özel okullar; temizlik personelleri, güvenlik görevlileri ve büro personelinin kısa çalışma ödeneğinden faydalandırmışlardır. Eğitim faaliyeti uzaktan eğitim yoluyla devam ettiği için öğretmenlerin çalışmaya devam etmesi nedeniyle kısa çalışma ödeneğinden faydalandırılması da tartışmalı bir uygulama olarak görülebilir.

Çalışma sonucunda ortaya çıkan tartışmalı durumlar, etik ve etik dışı olmak üzere iki bölümde incelenmiştir. Araştırmaya katılan velilerin yarısından fazlası özel okulların salgın süresince etik dışı uygulamaları olmadığını belirtmiştir. Veliler, çevrimiçi eğitime indirim yapan okulların etik davrandıklarını belirtmişlerdir. Veliler; yemek ücretlerinin peşin olarak alınması ve yemek ücretinin zorunlu tutulması, kitap ücretlerinin gereğinden fazla olması, kırtasiye ve okul kıyafetlerinin gereksiz pahalı olması, çevrimiçi eğitim şifrelerinin kitap almayanlara verilmemesi, öğretmenlerin işine son verilmesi, ücret iadesi sürecinde okul lehine kararlar alınmasını da etik dışı uygulamalar olarak görmüşlerdir. Yapılan birçok araştırmada uzaktan eğitimin hiçbir zaman yüz yüze eğitimle denk olamayacağı ortaya konulmuşken, özel okulların hiç bir şekilde ücret iadesi yapmaması, uzaktan eğitime denk tutulması yeniden değerlendirilmesi gereken etik bir konu olabilir. Özel okullar, uzaktan eğitimi ders sayısı olarak vermiş olabilirler, fakat verdikleri bu ders sayısının ne kadarını öğrencinin tam anlamıyla öğrendiği önemlidir. Çünkü öğrencilerin çevrimiçi öğrenmeye yönelik alg1sı ve hazır olma durumunun nasıl olduğu net olarak bilinmemektedir. Öğrenciler kendilerini birden bire uzaktan eğitim içerisinde bulmuşlardır. Güney New Hampshire Üniversitesi Başkanı LeBlanc (2020) COVID-19’un üniversiteleri çevrimiçi öğrenmede; öğrencilerin plansız ve tedirgin oldukları için çevrimiçi öğrenmeye karşı direnç olabileceğini belirtmiştir. Gana'da üniversite öğrencileri arasında yapılan başka bir araştırmada ise; öğrencilerin çevrimiçi öğrenmeye karşı hazırlıksız olduğu, zaman 
yönetimi ve özdenetim konusunda sorunlar olduğu belirlenmiştir (Agormedah, Henaku, Ayite ve Ansah, 2020). Üniversite öğrencilerinde uzaktan öğrenmeye karşı durum bu ise; yaşları daha küçük olan ilkokul ve ortaokul öğrencilerinin durumunun çok da farklı olacağını düşünmek iyimserlik olabilir. Ayrıca; Endonezya'da yapılan araştırmada öğrenciler ilk iki haftadan sonra çevrimiçi öğrenmeden sıkılmaya başlamışlardır (Irawan, Dwisona ve Lestari, 2020). Bu durum öğrenmeyi etkileyen önemli bir etkendir. Öğrenci, çevrimiçi olarak bilgisayarın başında fakat öğrenme gerçekleşmemiş olabilir.

Salgın sürecinde yaşanan ekonomik sıkıntılar ve eğitimin çevrimiçi olması sebebiyle özel okullarda yaşanan öğrenci kaybı velilerden gelen bulgulara göre hem okulların hem de velilerin yararı düşünülerek düzeltilirse her iki tarafın da kazanacağı düşünülmektedir. COVID-19 Türkiye'de de sosyal felaket olarak kabul edilmelidir. Böyle bir durumda, sözleşme taraflarının menfaatlerinin dengelenmesi hukuk güvenliği ve adaletin yerine getirilmesi açısından önemlidir. Bunun nasıl gerçekleştirileceği ayrı bir sözleşmeye göre yapılmalıdır (Yılmaz, 2020). Zira eğitimi sadece öğretmenlerin, öğrencilere bilgi aktarımı olarak görmek özellikle bu çağda hem eğitime hem de öğretmenlere yapılan büyük bir haksızlıktır. Eğer, eğitimi sadece bilgi aktarımı olarak tanımlarsak ne okullara ne de öğretmenlere ihtiyaç vardır. Bu bilgi aktarımını öğrenci tek başına bilgisayarı kullanarak yapabilir. Bu tarz anlayışların önüne geçilmesi ve her iki tarafin ortak paydada birleşmesi için hukukçu ve eğitimcilerden oluşan özel okullarla hiçbir organik bağ1 olmayan bir komisyon her iki tarafin isteklerini dinleyip, özel okul velileri ve özel okul sahiplerinin uzlaşması için arabuluculuk görevi üstlenmelidir. Çünkü iki taraf arasında uzlaşma sağlanması, MEB’in 2023 hedeflerine bir adım daha yaklaşmasına yol açacaktır

Milli Eğitim Bakanlığı yetkilileri problemin çözümü için özel okul velilerinin de görüşlerini dikkate almalıdırlar. Özel okullara ücretler konusunda sıkı bir denetim getirilmelidir Yemek ve kırtasiye ücretlerine yapılan ücret artışarı takip edilmelidir. Veliyi yemek ve kırtasiye malzemelerini almaya mecbur bırakan okullara gerekli yasal yaptırımlar uygulanmalıdır. Araştırmacılar, özel okul çalışanlarının salgın sürecinden nasıl etkilendiklerini, özel okulların tercih edilmesindeki nedenlerin değişip değişmediğine yönelik farklı araştırma tekniklerini kullanarak araştırma yapabilirler. Ayrıca araştırmacılar, özel okul öğrencilerinin çevrimiçi eğitim sürecinde öğrenmeyi ne kadar gerçekleştirdiklerini ortaya koyan araştırmalar da yapabilirler. Sonuç olarak önemli bir değer olarak şu çıkarımda bulunabiliriz; eğitim bir insan hakkıdır, bu hakkı gerçekleştirmek için özel okuldan hizmet satın alarak, devleti bir ölçüde rahatlatan vatandaş ve özel okullar arasında Milli Eğitim Bakanlı̆̆ uzlaştırmacı bir rol üstlenmelidir.

\section{Etik Beyan}

"COVID-19 Salgen ve Öžl Okul Ücret Politikalar: Kanuni ve Etik Çıarmlar” başlıklı çalışmanın yazım sürecinde bilimsel kurallara, etik ve alıntı kurallarına uyulmuş; toplanan veriler üzerinde herhangi bir tahrifat yapılmamış ve bu çalışma herhangi başka bir akademik yayın ortamına değerlendirme için gönderilmemiştir. Gerekli olan etik kurul izinleri Kafkas Üniversitesi Sosyal ve Beşeri Bilimler Bilimsel Araştırma ve Yayın Etiği Kurulu'nun 27.05.2021 tarih ve 20 sayılı toplantısında alınmıştır.

\section{Kaynakça}

Agormedah, E. K., Henaku, E. A., Ayite, D. M. K. ve Ansah, E. A. (2020). Çevrimiçi learning in higher education during COVID-19 pandemic: A case of Ghana. Journal of Educational Technology \& Cevrimigi Learning, 3(3), 183210.

Aslan, A. E. (2019). Türkiye'de özel okullaşma. BEÜ SBE Dergisi, 8(1), 263-276.

Bahçeşehir Universitesi (2020). BAU Uzaktan Eğitim Raporu, https://bau.edu.tr/haber/15707-bauzaktan-egitimraporu. Erişim tarihi:29.08.2020.

Bao, X., Qu, H., Zhang, R. ve Hogan, T. P. (2020). Modeling reading ability gain in kindergarten children during COVID-19 School closures. International Journal of Environmental Research and Public Health, 17(17), 6371.

Barskanmay, A. (2020, 13 Mayıs). Özel Okullara Gün Doğdu. https://www.karar.com/yazarlar/alibarskanmay/ozel-okullara-gun-dogdu-1562841

Bigirwa, J. P., Ndawula, S. ve Naluwemba, E. F. (2020). Does the school financing role matter in e-learning adoption? An explanatory sequential study in midwifery schools in Uganda. Contemporary Educational Technology, 12(1), Article ep264.

BKM (2020). Seçilen Sektöre Göre Aylık Gelişim: Eğitim sektörü harcamalar1 2019-2020. Aralık 2020, https://bkm.com.tr/secilen-sektore-gore-aylik gelisim/?filter_group $=22 \&$ List $=$ Listele\&as_fid $=326 c 6 a e d 06 b 5 e 85170 b 4 b 095 e e 3238 c 0 a 145 c 3 a b$

Bulut, A. (2020, 14 Mayıs). Koronavirüs (COVID-19) Pandemisinin Özel Okul Ücretlerine Etkisi: Ödeme-İade Problemi. https://blog.lexpera.com.tr/koronavirus-pandemisinin-ozel-okul-ucretlerine-etkisi-odeme-iadeproblemi/ 
Daniel, J. (2020). Covid-19 - A two-week transition from campus to online at the Acsenda School of Management. Canada. http://oasis.col.org/handle/11599/3701.

Eren, F. (2016). Borçlar Hukuku Genel Hükümler, 20. Baskı, Ankara 2016

Gonzalez, D., Karpman, M., Kenney, G. M. ve Zuckerman, S. (2020). Hispanic Adults in Families with Noncitizens Disproportionately Feel the Economic Fallout from COVID-19.

Gülbahar, Y. (2009). E-ögrenme. Ankara: Pegem Akademi.

Gündüz, M. (2016). Tanzimat döneminde özel öğretimin başlaması ve Ahmed Cevdet Paşa'dan ilginç bir rapor. Eğitime Bakıs, 12(38), 11-17.

Hukuki Haber. (2020, 23 Nisan). COVID-19 Salgını ve Mücbir Sebep Kapsamında Özel Öğetim Kurumları İçin Durum Değerlendirmesi. https://www.hukukihaber.net/makale/COVID-19 -salgini-ve-mucbir-sebepkapsaminda-ozel-ogretim-kurumlari-h436204.html\#_ftn34 .

Irawan, A. W., Dwisona, D. ve Lestari, M. (2020). Psychological impacts of students on online learning during the pandemic COVID-19. KONSELI: Jurnal Bimbingan dan Konseling (E-Journal), 7(1), 53-60.

Ilgar, L. (2014). Özel okul ve devlet okulunda görev yapmış sınıf öğretmenlerinin sınıf yönetimindeki farklılıklara ilişkin görüşleri: Nitel bir çalışma. Hasan Ali Yücel Ë̈̆tim Fakültesi Dergisi, 11(22), 259-285.

İSKKUR (2020). Kısa Çalışma Ödeneği. https://www.iskur.gov.tr/isveren/kisa-calisma-odenegi

Kamudan Haber. (2020, 6 Eylül). Özel Okul Öğretmenlerinin Maaşlarını Neden Devlet Ödüyor? https://www.kamudanhaber.net/guncel/ozel-okul-ogretmenlerinin-maaslarini-neden-devlet-oduyorh448135.html

Kaplan, P. (2020). Uzaktan eğitim özel okullarda öğrenci sayısını 310 bin azalttı. http://www.pervinkaplan.com/detay/uzaktan-egitim-ozel-okullarda-ogrenci-sayisini-310-bin-azaltti/13668.

Kidson, P. Andrew. (2020). Some private schools need to change their models - they were losing students even before COVID. The Conversation, $1-5$ October https: / / ro.uow.edu.au/cgi/viewcontent.cgi?article=1266\&context=asshpapers.

Korlu, Ö. (2020). Eğitimin yönetişimi ve finansman eğitim i žleme raporu 2020. https:/ /www.egitimreformugirisimi.org/wpcontent/uploads/2010/01/EIR2020_EgitimYonetisimiVeFinansmani.pdf.

LeBlanc, P. (2020). COVID-19 has thrust universities into online learning-how should they adapt? https://www.brookings.edu/blog/education-plus-development/2020/03/30/covid-19-has-thrust-universitiesinto-online-learning $\% \mathrm{E} 2 \% 81 \% \mathrm{~A} 0$-how-should-they-adapt/

Lodico, M. G., Spaulding, D. T. ve Voegtle, K. H. (2010). Methods in educational research: From theory to practice (Vol. 28). New York: John Wiley \& Sons.

Mbogo, R. W. (2020). Leadership roles in managing education in crises: The case of Kenya during COVID-19 pandemic. European Journal of Education Studies, 7(9), 207-226.

Mandhani, A. (2020). 5 July, 2020 9:22 am IS.https://theprint.in/judiciary/school-fee-payment-plea-reaches-sc-alook-at-how-12-hcs-ruled-on-the-issue-since-april/454614/.

Merriam, S. B. (1998). Qualitative research and case study applications in education. Revised and expanded from case study research in education. San Francisco: Jossey-Bass Publishers.

MEB. http://sgb.meb.gov.tr/www/milli-egitim-istatistikleri-yayinlanmistir-orgun-egitim-20192020/icerik/397.

MEB. http://2023vizyonu.meb.gov.tr/doc/2023_EGITIM_VIZYONU.pdf.

MEB (2020). Özel Öğretim Kurumları Genel Müdürlüğü’nün 16.03.2020 tarih ve 556022 Esas say1l yazıs1.

MEB (2020). Özel Öğretim Kurumları Genel Müdürlüğü’nün 07.04.2020 tarih ve 6215860 Esas sayılı "Korona Virüs Tatili ve Özel Kurumların Ücretleri” isimli yazısı.

Miles, M, B. ve Huberman, A. M. (1994). Qualitative data analysis: An expanded sourcebook (2 ${ }^{\text {nd }}$ Edition). Thousand Oaks, CA: Sage.

Nartgün, Ş. ve Kaya, A. (2016). Özel okul velilerinin beklentileri doğrultusunda okul imajı oluşturma. Ĕgitim ve Öğretim Arassttrmalar Dergisi, $5(2)$ Makale No: 17.

Nicola, M., Alsafi, Z., Sohrabi, C., Kerwan, A., Al-Jabir, A., Iosifidis, C., Agha, M. ve Agha, R. (2020). The socioeconomic implications of the coronavirus pandemic (COVID-19): A review. International Journal of Surgery, 78, 185-193. .

Oran Kalkınma Ajansı. (2016). Özel Okul Yatırım https://www.oran.org.tr/images/dosyalar/20170915103310_0.pdf

Öztürk, A., B. (2018). Özel Eğitim Sektörü, Türkiye İşbankası, https://ekonomi.isbank.com.tr/ContentManagement/Documents/sr201801_ozelegitimsektoru.pdf

Seçkinler Grup. (2020). COVID-19 ve Kısa Çalışma Ödeneği. https://www.seckinlergrup.com/kisacalisma/?pdf $=1464$

T.C. Resmi Gazete: 14 Şubat 2007. 5580 Nolu Özel Öğretim Kurumları Kanunu, , Sayı: 26434,Erişim https://resmigazete.gov.tr/ fihrist?tarih=2007-02-14Son Erişim Tarihi: 16.12.2020.

T.C. Resmi Gazete: 14 Şubat 2007. 5580 Nolu Özel Öğretim Kurumları Kanunu, Sayı: 26434,Erişim https://resmigazete.gov.tr/fihrist?tarih=2007-02-14Son Erişim Tarihi: 16.12.2020.

T.C. Resmi Gazete: 19 Şubat 202031044 Saylı Resmi Gazete, Özel Okul Ücretleri, https:/ / www.resmigazete.gov.tr/fihrist?tarih=2020-02-19. 14.Son Erişim Tarihi: 16.12.2020. 
T.C. Çalışma ve Sosyal Güvenlik Bakanlığı İş Teftiş Kurulu Başkanlığı (2015). “Özel Öğretim Kurumlarında Çalışan İşçilerin Çalışma Koşullarının İyileştirilmesi Programlı Teftiş Raporu”. Ankara

TÜİK (2020). Eğitim harcamaları istatistikleri 2019. Aralık 2020, https://data.tuik.gov.tr/Bulten/Index?p=EgitimHarcamalari-Istatistikleri-2019-33670

TEDMEM (2020). COVID-19 sürecinde eğitim: Uzaktan öğrenme, sorunlar ve çözüm önerileri. TEDMEM Analiz. Dizisi 7. Ankara: Türk Eğitim Derneği Yayınları.

UNICEF (2020). Framework for reopening schools. https://www.unicef.org/sites/default/files/202006/Framework-for-reopening-schools-2020.pdf.

World Bank. (2015). Back to school after the Ebola outbreak. https://www.worldbank.org/en/news/feature/2015/05/01/back-to-school-after-eb ola-outbreak.

World Bank Report Education (2020). The COVID-19 Pandemic: Shocks to education and policy responses. Retrieved from $\quad$ May, 2020. https://openknowledge.worldbank.org/bitstream/handle/10986/33696/148198.pdf

Yılmaz, Ç. M. (2020). COVID-19'un özel okul sözleşmelerinde edimlere etkisi. Sosyal Bilimlerde Yeni AraştırmalarIV (Edt: E. İslamoğlu ve E. Alp), Berikan Yayınevi: Ankara. ss. 13-22.

Zhou, T. (2020). ERS Brrefing - Financial Implications of COVID-19: Capturing FY20 Savings (or Not) in School Districts. https:/ / files.eric.ed.gov/ fulltext/ED607263.pdf.

https://ookgm.meb.gov.tr/www/ogrenci-kayit-sozlesmesi/icerik/1423

http://ookgm.meb.gov.tr/www/sss.php.Özel okullar.

\section{EXTENDED ABSTRACT}

With the effect of COVID-19, the crisis waves in the world have shown themselves in every field. One of the sectors is education, which has been most affected by these crisis waves. With the COVID-19 pandemic, the traditional face-to-face training has been replaced by digital education. With the effect of COVID-19, the crisis waves in the world have shown themselves in every field. Education is one of the sectors most affected by these crisis waves. With the COVID-19 pandemic, the traditional face-to-face training has been replaced by digital education. Before the pandemic, many private schools in the world had been conducting synchronous and asynchronous education to support face-to-face education. With the pandemic, the transfer of education to the online space carried education in private schools to the expectations law and education triangle. The purpose of this research is to reveal the opinions of parents about the service and fee policies of private schools in the 2019-2020 academic year and in the 2020-2021 academic year, following the closure of schools and interruption of face-to-face education due to COVID19. Accordingly, answers to the following questions are searched:

1) What are the views of parents on the service and fee policies of private schools during the 20192020 academic year (the status of students' benefiting from the services provided, the satisfaction level of the parents, and the refund policy of private schools) during the pandemic?

2. What are the parents' opinions about the service and fee policies of private schools (reasons for parents' private school preference, student registration agreements, the number and duration of distance education courses) during the 2020-2021 academic year?

3. During the current pandemic, are there unethical practices in private schools due to service and fee policy? What are the parents' opinions about these practices?

It was thought that only qualitative or quantitative information would not be sufficient to answer the research questions, and the mixed method and enriched (triangulation) parallel mixed design were used in the study. Findings have been examined under the themes of private school education expenditures of households, the status of student enrollment agreements in private schools, student enrollment in private schools, services not covered in private schools, and private schools' fee refund policies for these services, state support to private schools, and reduction in costs of private schools during the Covid-19 outbreak.

According to the findings, although the education expenditures made by households in Turkey are quite high compared to other countries, there has been a great decrease in education sector expenditures in 2020. There has been a decrease in private school enrollment and a decrease in the number of private schools in the 2020-2021 enrollment period. The force compelling clause in the student enrollment agreements refers to the situations where the obligations arising from the contract can no longer be fulfilled and the basic nature of the bargaining between the parties has changed. Participants stated that they were uncomfortable about the method of the refund, the duration of the fee and the rate of the refund. Participants stated that they encountered unethical practices of private schools regarding fee policy during the pandemic. They defined these unethical practices as compulsory services at the request of the 
parents, making decisions in favor of the school regarding the reimbursement, the cost of the book being more than it should be, and disrupting education by terminating teachers' jobs. During the COVID-19 pandemic, the costs of private schools decreased and private schools also benefited from various government support. Teachers and other staff working in private schools were able to benefit from shorttime working allowance. With this allowance, it is prevented that branch teachers who are not or partially possible to be given through distant education are faced with dismissal. COVID-19 should be considered as a social disaster in the world and in Turkey. In such a situation, balancing the interests of the contracting parties is important in terms of legal security and justice. It should be done according to the individual contract (Yllmaz, 2020). Loss of students in private schools due to the economic difficulties experienced during the pandemic and the online education, according to the findings from the parents, it is thought that if it is corrected considering the benefits of schools and parents, both sides will win.

Especially in this period seeing education as the way of knowledge transfer by teachers to students is a great injustice to both education and teachers. If we define education only as the transfer of knowledge, neither schools nor teachers are needed. The student can get this information by using the computer alone. For this reason, a commission consisting of lawyers and educators that has no organic ties with private schools should listen to the requests of both parties and act as a mediator for the reconciliation of private school parents and private school owners. The Ministry of National Education should listen to the requests of the parents of private schools and provide necessary assistance when they are justified. 